\title{
$\beta$-catenin promotes the type I IFN synthesis and the IFN-dependent signaling response but is suppressed by influenza A virus-induced RIG-I/NF-KB signaling
}

\author{
Andrea Hillesheim, Carolin Nordhoff, Yvonne Boergeling, Stephan Ludwig and Viktor Wixler*
}

\begin{abstract}
Background: The replication cycle of most pathogens, including influenza viruses, is perfectly adapted to the metabolism and signal transduction pathways of host cells. After infection, influenza viruses activate several cellular signaling cascades that support their propagation but suppress those that interfere with viral replication. Accumulation of viral RNA plays thereby a central role. Its sensing by the pattern recognition receptors of the host cells leads to the activation of several signal transduction waves that result in induction of genes, responsible for the cellular innate immune response. Type I interferon (IFN) genes and interferon-stimulated genes (ISG) coding for antiviral-acting proteins, such as MXA, OAS-1 or PKR, are primary targets of these signaling cascades. $\beta$ - and $\gamma$-catenin are closely related armadillo repeat-containing proteins with dual roles. At the cell membrane they serve as adapter molecules linking cell-cell contacts to microfilaments. In the cytosol and nucleus, the proteins form a transcriptional complex with the lymphoid enhancer factor/T-cell factor (LEF/TCF), regulating the transcription of many genes, thereby controlling different cellular functions such as cell cycle progression and differentiation.

Results: In this study, we demonstrate that $\beta$ - and $\gamma$-catenin are important regulators of the innate cellular immune response to influenza A virus (IAV) infections. They inhibit viral replication in lung epithelial cells by enhancing the virus-dependent induction of the IFNB1 gene and interferon-stimulated genes. Simultaneously, the prolonged infection counteracts the antiviral effect of $\beta$ - and $\gamma$-catenin. Influenza viruses suppress $\beta$-catenin-dependent transcription by misusing the RIG-I/NF-KB signaling cascade that is induced in the course of infection by viral RNA.
\end{abstract}

Conclusion: We identified $\beta$ - and $\gamma$-catenin as novel antiviral-acting proteins. While these factors support the induction of common target genes of the cellular innate immune response, their functional activity is suppressed by pathogen evasion.

Keywords: Influenza A virus, Innate immune response, $\beta$-catenin, $\gamma$-catenin, Interferon- $\beta$, Interferon-stimulated genes, $\beta$-catenin-dependent target genes

\section{Background}

Influenza A viruses (IAV) represent worldwide circulating pathogens that cause seasonal epidemics but also occasionally lead to severe pandemic outbreaks. These viruses belong to the family of orthomyxoviridae and consist of a single-stranded RNA genome with negative orientation, which is organized in eight RNA segments. The RNA

\footnotetext{
*Correspondence: vwixler@uni-muenster.de

Institute of Molecular Virology (IMV), Centre for Molecular Biology of Inflammation (ZMBE), Westfaelische Wilhelms-University Muenster, Von-Esmarch-Str. 56, 48149
} Muenster, Germany strands encode up to 14 viral proteins including structural and non-structural (NS) proteins [1-4]. Some of these, such as NS1 or PB1-F2, are adapted to prevent cellular and host immunity by manipulating multiple host signaling cascades [5-7]. Virus-infected cells generally respond to infection by induction of an innate immune response that is initiated by several cellular pattern recognition receptors (PRRs), which detect specialized pathogenassociated molecular pattern (PAMPs) molecules. In the case of IAV infections, the family of cytoplasmic retinoic acid-inducible gene-like (RIG-I) receptors are sensors for 
accumulating viral $5^{\prime}$-triphosphate RNA $[8,9]$, resulting in the activation of the first line of defense, the type I interferon (IFN) response. This comprises the expression of IFN- $\alpha / \beta$ and the subsequent transcriptional activation of interferon-stimulated genes (ISG) [10].

Secreted IFN- $\beta$ itself does not have direct antiviral action, but it induces in an auto- and paracrine manner the expression of antiviral-acting genes [10-12]. Binding of IFN- $\beta$ to the type I interferon receptor (IFNAR1) activates the JAK/STAT signaling cascade. This results in formation of the IFN-stimulated gene factor 3 (ISGF3) protein complex consisting of the signal transducers and activators of transcription 1/2 (STAT1/2) and the interferon regulatory factor 9 (IRF9). This protein complex translocates into the nucleus and binds to IFN-stimulated response elements (ISRE) on the promoters of several ISGs [10], such as myxovirus resistance gene a (MX1) [13], 2-5-oligoadenylate synthetase (OAS) [14] or protein kinase R (EIF2AK2) [15], thereby initiating their transcription. The translated proteins of these ISGs directly or indirectly interfere with virus replication and, thus, limit virus spread.

The highly conserved $\beta$-catenin protein is the vertebrate's homologue of Drosophila armadillo. It consists of 781 amino acids, which form 12 so called armadillo repeats that are responsible for interactions with several proteins, such as cadherins, $\alpha$-catenin, adenomatous polyposis coli (APC) or lymphoid enhancer factor/T-cell factor (LEF/TCF) [16-18]. In unstimulated cells, most $\beta$ catenin molecules function as adapter molecules at the cell membrane, linking cadherin receptors to the actin cytoskeleton. Simultaneously, a minor cytosolic pool of $\beta$-catenin acts upon association with LEF/TCF as a transcription factor. The relation between adhesional and transcriptional pools is dynamic and is regulated via phosphorylation of $\beta$-catenin at different amino acids at both the $\mathrm{N}$ - and the C-termini [19].

Most of the regulation of the $\beta$-catenin signaling cascade is mediated by the glycogen synthase kinase $3 \beta$ (GSK-3 $\beta$ ) and casein kinase $1 \alpha(\mathrm{CK} 1 \alpha)$ [20]. In unstimulated cells, they form a cytoplasmic protein degradation complex with axin, APC and the protein phosphatase 2A (PP2A). When bound to this complex, $\beta$-catenin is phosphorylated by the kinases at amino acids Ser33, Ser37, Thr41 and Ser45. The hyperphosphorylated $\beta$-catenin is then ubiquitinylated by the $\beta$-transducin repeat-containing protein $(\beta-\operatorname{TrCP})$ and subsequently degraded by the $26 \mathrm{~S}$ proteasome $[20,21]$. Activation of the Wnt signaling cascade leads to the dissociation of the degradation complex [22,23] and inactivation of the GSK-3 $\beta$ via phosphorylation at Ser9 [24]. Consequently, the non-phosphorylated $\beta$-catenin is released and interacts with LEF/TCF, forming a transcriptional complex that induces, together with other co-factors like CBP/ p300, the expression of many genes. The most prominent of these are the cell cycle inducing cyclin D1 $[25,26]$ and the transcription factor c-Myc [27]. Besides Wnt factors [24], stimulation of cells with insulin [28], EGF [29] or inducers of the PI3K [30] also might result in inactivation of GSK-3 $\beta$ and transcriptional activation of $\beta$-catenin.

The $\gamma$-catenin molecule, also known as plakoglobin, is a very close homologue of $\beta$-catenin. It is also able to exert a dual role within the cell and act as an adapter molecule [31] and, in concert with LEF/TCF, as a transcription factor, regulating the expression of common $\beta$ catenin target genes, although to a lesser extent than $\beta$-catenin itself $[32,33]$.

During IAV infection, several cellular signaling cascades are activated that may support or inhibit viral replication. The PI3K/Akt signaling axis is a prominent pathway with a dual action with respect to influenza viruses [34]. Activation of this pathway also results in the phosphorylation of GSK-3 $\beta$ at Ser9 [30], suggesting an accumulation and activation of $\beta$-catenin during IAV infection.

In this study, we demonstrate that $\beta$-catenin and its closely related homolog $\gamma$-catenin are important regulators of the innate cellular immune response to IAV infections. They inhibit virus replication in lung epithelial cells by enhancing the virus-dependent induction of the type I IFN system. However, the transcriptional activity of $\beta$-catenin is simultaneously inhibited upon viral infection by the RIG-I signaling cascade that is induced by influenza viral RNA.

\section{Results}

\section{Accumulation of $\beta$ - and $\gamma$-catenin decreases influenza $A$} virus propagation

To elucidate whether accumulation of cellular $\beta$-catenin influences viral replication, we overexpressed the protein in human lung epithelial A549 cells by plasmid transfection prior to IAV infection and subsequently analyzed the efficiency of viral propagation. To ensure that the recombinant $\beta$-catenin is not degraded by the proteasome, the phosphorylation-refractory $\beta$-catenin substitution mutant S33A [35] was used. A549 cells, transfected with empty vector, served as control and the expression efficiency of the transgene was monitored by Western blot analysis (Figure 1A). As shown in Figure 1B overexpression of the transcriptionally active $\beta$-catenin significantly impaired the replication of avian FPV (A/FPV/ Bratislava/79 (H7N7)) influenza A viruses compared to vector control-transfected cells. Because $\beta$-catenin exerts its gene expression function in concert with the transcription factor LEF1, the effect of their co-expression was analyzed as well and indeed LEF1 boosted the anti- 


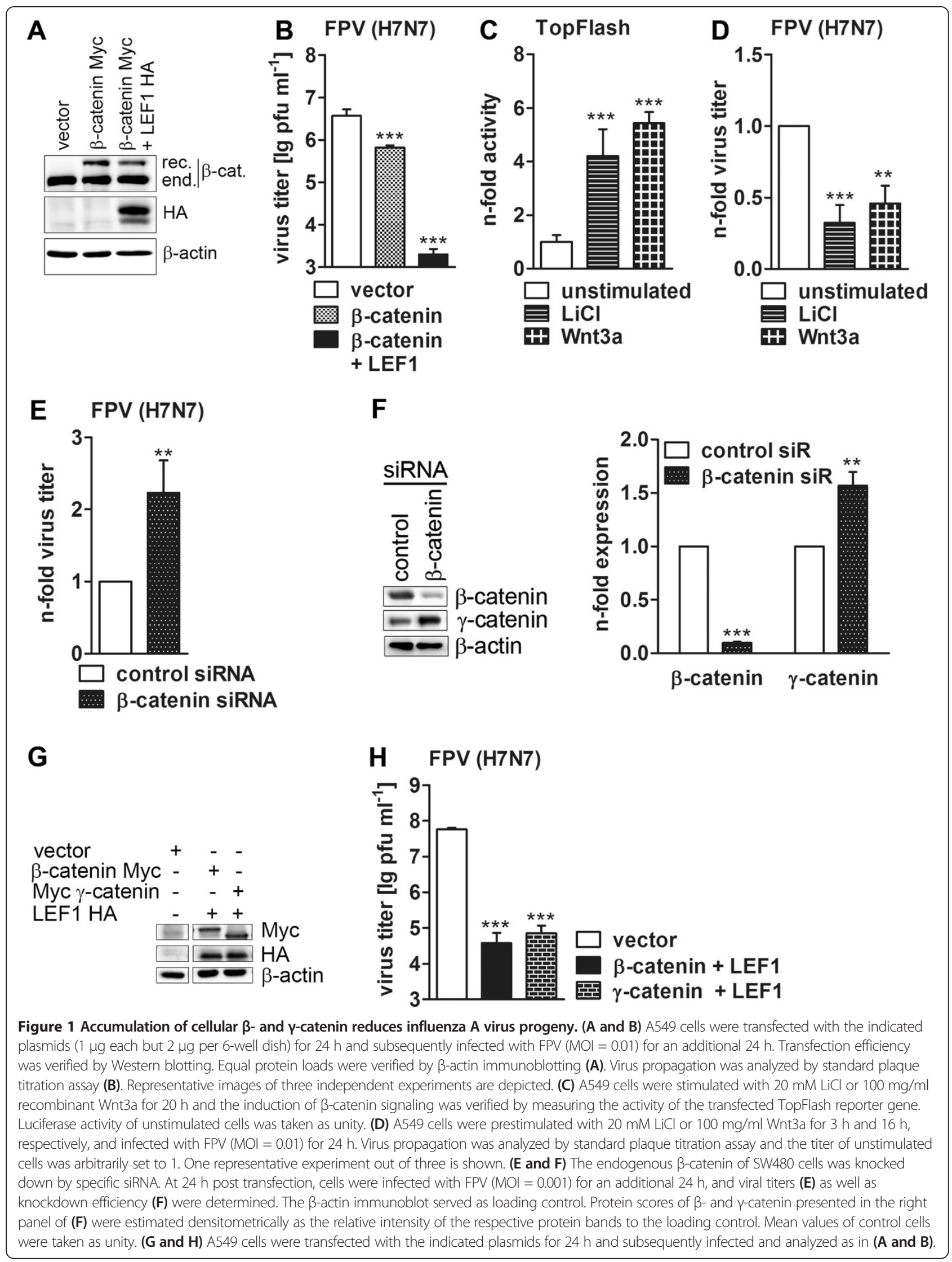


viral effect of $\beta$-catenin on FPV replication dramatically (Figures $1 \mathrm{~A}$ and $\mathrm{B}$ ).

To further explore whether the accumulation of endogenous $\beta$-catenin also inhibits virus replication, the intracellular pool of $\beta$-catenin was augmented by stimulation of A549 cells with either lithium chloride ( $\mathrm{LiCl}$ ) or the glycoprotein Wnt3a. $\mathrm{LiCl}$ is a commonly used drug for treatment of bipolar disorders with clinical relevance for more than 50 years and is known to inhibit the GSK$3 \alpha$ and $\beta$ isoforms [36]. Wnt3a is a known activator of the canonical Wnt signaling cascade. To confirm that both stimuli lead to accumulation of transcriptionally active $\beta$-catenin, A549 cells were transfected with a $\beta$ catenin/LEF1-dependent TopFlash reporter construct harboring LEF/TCF binding sites upstream of the thymidine kinase minimal promoter [35] for $24 \mathrm{~h}$ and stimulated with $\mathrm{LiCl}$ or Wnt3a for further $20 \mathrm{~h}$. Measuring the luciferase activity of the reporter gene product showed that the TopFlash-specific promoter activity was indeed significantly increased by both stimuli (Figure 1C). Next, A549 cells were prestimulated with $\mathrm{LiCl}$ for $3 \mathrm{~h}$ or with Wnt3a for $16 \mathrm{~h}$ and subsequently infected with avian FPV in the presence of the stimuli for an additional $24 \mathrm{~h}$. Both $\mathrm{LiCl}$ and Wnt3a stimulation of A549 cells reduced virus propagation by approximately $50 \%$ (Figure 1D).

To further confirm the antiviral properties of endogenous $\beta$-catenin, its amount was downregulated by an siRNA approach. For this purpose, SW480 colon carcinoma cells were used. They carry mutations in the APC gene that prevent formation of the protein degradation complex and result in accumulation of intracellular $\beta$ catenin [37-39]. As expected, the RNAi-based downregulation of $\beta$-catenin was associated with an increase in viral replication (Figure 1E). Although the differences in viral titers were significant compared to cells transfected with control siRNA, the effect was, nonetheless, much less than expected. This might be due to the simultaneous increase in $\gamma$-catenin expression in colon carcinoma cells that occurs upon $\beta$-catenin knockdown (Figure 1F), a fact that has been previously described for hepatocytes [40]. This suggests that $\gamma$-catenin also might be involved in reducing viral propagation. And indeed, we could show that this protein also possesses antiviral potential, since in cells overexpressing $\gamma$-catenin along with LEF1 (Figure 1G) a significant decrease in viral replication compared to cells overexpressing control vectors was observed (Figure $1 \mathrm{H}$ ). Analysis of viral replication in cells with downregulated expression of both $\beta$ - and $\gamma$ catenin was not possible, as RNAi-knockdown of both proteins led to cell death shortly after virus infection (data not shown).

As inactivation of GSK-3 $\beta$ is one of the causes for cellular accumulation of endogenous transcriptionally active $\beta$-catenin [41], we monitored the phosphorylation status of GSK-3 $\beta$ at Ser9 by Western blotting after infection of cells with the avian FPV (A/FPV/Bratislava/79 (H7N7)) or human PR8 (A/Puerto Rico/8/34 (H1N1)) influenza virus strains (Additional file 1: Figures S1A and B). The phosphorylation of Ser9 was detectable after infection with both IAV strains from $6 \mathrm{~h}$ p.i. and lasted at least up to $10 \mathrm{~h}$ p.i., thus, showing that infection of cells with influenza viruses results in inactivation of GSK-3 $\beta$ and assuming an accumulation of endogenous $\beta$-catenin within the cell. Indeed, analysis of cytosolic and nuclear $\beta$-catenin levels confirmed this and showed that infection of cells with influenza viruses resulted, similar to Wnt3a stimulation, in accumulation of cellular $\beta$-catenin protein, mostly in the nucleus (Figure 2).

Taken together, these data show that accumulation of transcriptionally active $\beta$-catenin or $\gamma$-catenin impairs IAV propagation.

\section{Catenins regulate interferon- $\beta$ induction}

The innate immune response of virus-infected cells is primarily governed by rapid transcription, translation and secretion of IFN- $\beta$, which is triggered by the accumulation of newly produced viral RNA. Subsequently, secreted IFN- $\beta$ acts in an auto- and paracrine fashion to induce the expression of proteins coded by interferonstimulated genes that, in turn, suppress viral propagation [10]. Thus, we wondered whether accumulation of intracellular $\beta$-catenin is involved in regulating the IFN- $\beta$ induction and thereby executes its antiviral potential. To explore this, A549 cells were transiently co-transfected with $\beta$-catenin and LEF1 together with a luciferase reporter gene construct driven by the IFN- $\beta$ enhanceosome, a promoter element that contains all principal transcription factor binding sites of the IFN- $\beta$ promoter. Twenty-four hours post transfection, the cells were stimulated for an additional $5 \mathrm{~h}$ with total RNA isolated from non-infected (cellular RNA) or influenza A virusinfected (viral RNA) A549 cells. The latter RNA sample is mimicking the release of viral RNA upon IAV infection. Overexpression of the $\beta$-catenin/LEF1 complex significantly increased the IFN- $\beta$ enhanceosome activity (Figure 3A), suggesting that $\beta$-catenin and LEF1 strongly support the transcription of the IFNB1 gene in lung epithelial cells. Interestingly, the $\beta$-catenin/LEF1-mediated induction of IFN- $\beta$ transcription could be measured independently of whether cells were stimulated with viral RNA or not.

Furthermore, the capability of $\beta$-catenin and LEF1 to stimulate IFN- $\beta$ induction was cell type-independent, as overexpression of these proteins in Vero cells showed a similar effect (Figure 3B). These cells are deficient in the production of type I IFNs [42] and, thus, represent a good tool for investigation of IFN response independently of the 


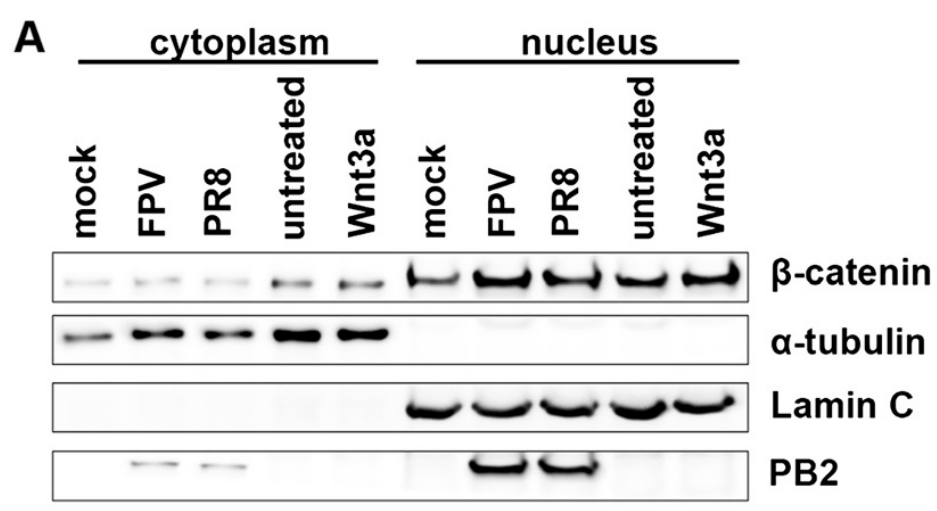

B

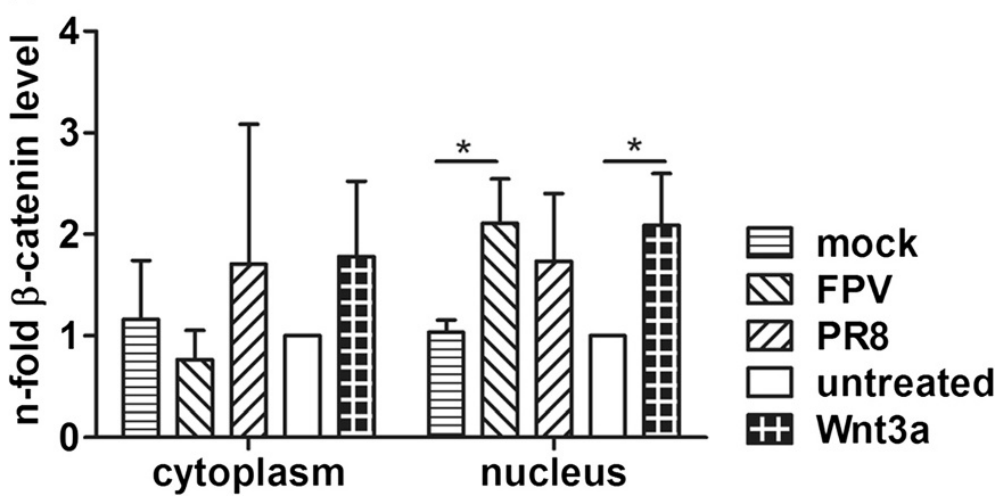

Figure 2 IAV infection induces nuclear accumulation of $\beta$-catenin molecules. HEK293 cells were stimulated with $100 \mathrm{mg} / \mathrm{ml} \mathrm{Wnt3a} \mathrm{or}$ infected with either FPV or PR8 $(\mathrm{MOI}=5)$ for $6 \mathrm{~h}$. Subsequently, cell lysates were fractionated and the cytosolic and nuclear fractions were analyzed by SDS-PAGE and Western blotting for $\beta$-catenin levels. (A) Immunoblotting of a-tubulin and Lamin C served as internal loading controls for cytosolic and nuclear fractions, respectively. The infection was verified by expression of viral PB2 protein. One representative Western Blot out of three is depicted. (B) Relative $\beta$-catenin protein scores of Western blots are presented. They were estimated densitometrically as the relative intensity of the appropriate protein band to the loading control and normalized to the cytoplasmic or nuclear fraction of untreated cells, respectively. Values are means of three independently repeated experiments.

IFN synthesis. Also here, expression of $\beta$-catenin and LEF1 enhanced the activity of the IFN- $\beta$ promoter, regardless of whether the cells were unstimulated or stimulated with RNA from virally-infected cells or synthetically 5 '-triphosphate modified RNA (pppRNA) that represents the typical structure of IAV vRNA (Figures 3B and C).

As $\gamma$-catenin exhibits similar antiviral activity as $\beta$ catenin (Figure $1 \mathrm{H}$ ), we questioned whether $\gamma$-catenin is also able to enhance IFN- $\beta$ enhanceosome activity. Figure 3D clearly demonstrates that, similar to $\beta$-catenin, $\gamma$-catenin significantly enhanced together with LEF1 the promoter activity, in unstimulated as well as in pppRNAstimulated cells.

IFN- $\beta$ is a secreted cytokine affecting cells in an autocrine and paracrine manner by binding to the type I IFN receptor. This induces a signaling cascade leading to the phosphorylation of the transcription factor signal transducer and activator of transcription 1 (STAT1) and expression of ISGs [10]. To analyze whether the enhanced
IFN- $\beta$ promoter activity induced by overexpression of $\beta$ catenin or $\gamma$-catenin together with LEF was also translated into increased expression and secretion of functional IFN$\beta$ molecules, freshly plated A549 cells were treated with supernatants of either control or catenin and LEF transfected cells and the phosphorylation of STAT1 at tyrosine 701 was monitored by Western blotting. The results of Figure 3E (right panel) clearly show that phosphorylation of STAT1 in A549 cells was increased after stimulation with supernatants from catenin and LEF1 overexpressing cells (Figure 3E, left panel), which is in accordance with the enhanced IFN- $\beta$ promoter activity.

The activity of the IFN- $\beta$ enhanceosome is dependent on members of three different transcription factor families, the interferon regulatory factors (IRFs), activator proteins (AP) and the nuclear factor kappa-light-chainenhancers of activated B-cells (NF-KB) that bind to the positive regulatory domains (PRD) in the promoter region of the IFNB1 gene [10]. To decipher which of these three 


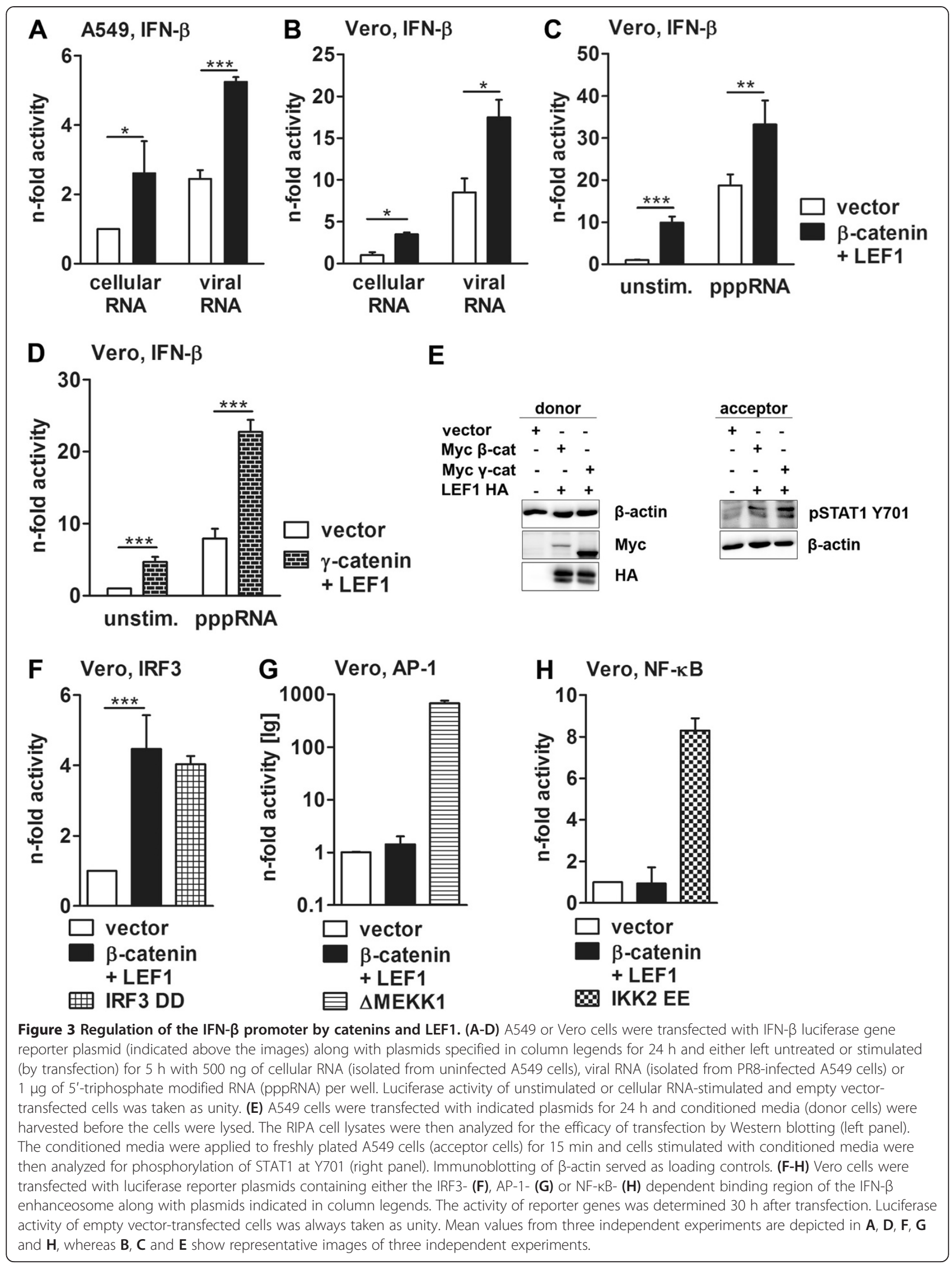


binding sites is supported by the $\beta$-catenin/LEF1 complex, reporter gene assays with constructs harboring sites for either IRF3, AP-1 or NF-кB were performed. Transfection of Vero cells with these constructs demonstrated that only the IRF3 (Figure 3F), but not AP-1 (Figure 3G) or NF-кB (Figure $3 \mathrm{H}$ ) responsive elements were efficiently activated by overexpressed $\beta$-catenin and LEF1. The inability of $\beta$-catenin and LEF1 to induce AP-1 and NF-KB PRD activation was not due to a functional inactivity of the used constructs, as expression of positive controls like constitutively active MEKK1 (mitogen-activated protein/extracellular signal-regulated kinase kinase kinase 1) or the inhibitor of kappa B kinase 2 (IKK2), respectively, were able to induce expression of the luciferase enzyme driven by these promoters (Figures $3 \mathrm{G}$ and $\mathrm{H}$, right columns). Hence, these data demonstrate that both $\beta$-catenin and $\gamma$ catenin are efficient stimulators of the IFN- $\beta$ promoter and that this activity is mainly executed via the IRF3specific region.

\section{$\beta$-catenin acts in concert with the $p 300$ transcription co-factor and binds the IFN- $\beta$ promoter}

It is known that the transcription factor IRF3 is the main driver of IFN- $\beta$ expression upon IAV infection. Accumulating viral RNA binds to and activates the intracellular RIG-I receptor, which signals via the adaptor protein MAVS (mitochondrial antiviral-signaling protein) to kinases such as TBK-1 (TANK-binding kinase 1) and IKKE (I-kappa-B kinase epsilon) which in turn phosphorylate IRF3. Phosphorylated IRF3 molecules form active dimers that migrate into the nucleus and initiate, together with $\mathrm{CBP} / \mathrm{p} 300$, IFN- $\beta$ transcription [43]. Furthermore, in independent experiments it has been shown that $\beta$-catenin directly interacts with IRF3 [44] and with CBP/p300 as well [45]. However, it is conceivable that the $\beta$-catenin/ LEF1 protein complex supports the IRF3-mediated transcription either by augmenting IRF3 phosphorylation and, hence, dimerization in the cytosol or directly as transcription factor in the nucleus. Although our experiments with cellular RNA-stimulated cells already suggested that $\beta$-catenin/LEF1 does not act in the IFN- $\beta$ activation pathway provoked by viral RNA, this was further affirmed via comparison of the dimerization capacity of IRF3 on stimulation with viral RNA in the absence or presence of $\beta$-catenin and LEF1 (Additional file 1: Figure S2). Thus, the $\beta$-catenin/LEF1 protein complex does not support the transcriptional activity of IRF3 via modulation of IRF3 dimerization but rather through enhancing its transcriptional activity in the nucleus.

It is known that phosphorylated IRF3 dimers recruit the acetyltransferase $\mathrm{CBP} / \mathrm{p} 300$ to the IFN $-\beta$ promoter [43] and, recently, Yang et al. showed that $\beta$-catenin also promotes the recruitment of $\mathrm{p} 300$ to the IFN- $\beta$ promoter via direct interaction with IRF3 [44]. These data together with the reporter gene assay and IRF3 gel shift results suggest that the $\beta$-catenin/LEF1 complex modulates the transcriptional activity of IRF3 in concert with the general co-activator $\mathrm{CBP} / \mathrm{p} 300$. To verify this assumption, the IRF3-dependent luciferase reporter gene activity in cells that overexpress only p300, $\beta$-catenin and LEF1 or all three proteins together were compared (Figure 4A). Overexpression of p300 alone already induced the IRF3-dependent promoter activity, but the extent was comparable to that of $\beta$-catenin and LEF1; however, when $\mathrm{p} 300$ was co-expressed with $\beta$-catenin and LEF1, the IRF3-promoting effect shown in Figure 3F was significantly enhanced (Figure 4A, right column).

To monitor whether the gain of promoter activity was due to binding of the $\beta$-catenin/LEF1 complex to the IFN$\beta$ enhanceosome, ChIP assays were performed (Figure 4B). As proof of principle, the endogenous IRF3 protein was precipitated with a specific antibody from control cells, transfected with vectors only, and the presence of IFN- $\beta$ promoter DNA in the immunoprecipitate was analyzed by qRT-PCR using primers specific for the IFN- $\beta$ promoter region. Importantly, IFN- $\beta$-specific signals could only be detected when the IRF3, but not the IgG-mediated immunoprecipitate was used as template in the qRT-PCR. Next, $\beta$-catenin was immunoprecipitated from vector or $\beta$ catenin and LEF1-transfected cells to demonstrate that $\beta$ catenin binds to the IFN- $\beta$ promoter. Using the DNA present in these immunoprecipitates as templates for qRT-PCR confirmed the association of $\beta$-catenin with the IFN- $\beta$ promoter region. Of note, both endogenous and recombinantly expressed $\beta$-catenin were able to bind the IFN- $\beta$ promoter, however, an increased signal was measured in immunoprecipitates from $\beta$-catenin- and LEF1-transfected cells. No signal was detected when immunoprecipitations were performed with unspecific IgG antibodies.

Taken together, these results indicate that the $\beta$ catenin/LEF1 complex stimulates the IRF3-dependent transcription of IFN- $\beta$ by interaction with the promoter DNA.

\section{Catenins potentiate ISG expression}

The fact that $\beta$-catenin positively regulates IFN- $\beta$ transcription suggests that expression of interferon-induced genes should, in turn, also be upregulated in the presence of the active $\beta$-catenin. This was indeed the case. Overexpression of $\beta$-catenin and LEF1 efficiently enhanced the synthesis of MxA mRNA in A549 epithelial cells (Figure 5A). The presence of exogenous $\beta$-catenin and LEF1 was also confirmed by qRT-PCR (Additional file 1: Table S1). Thus, one might further speculate that 

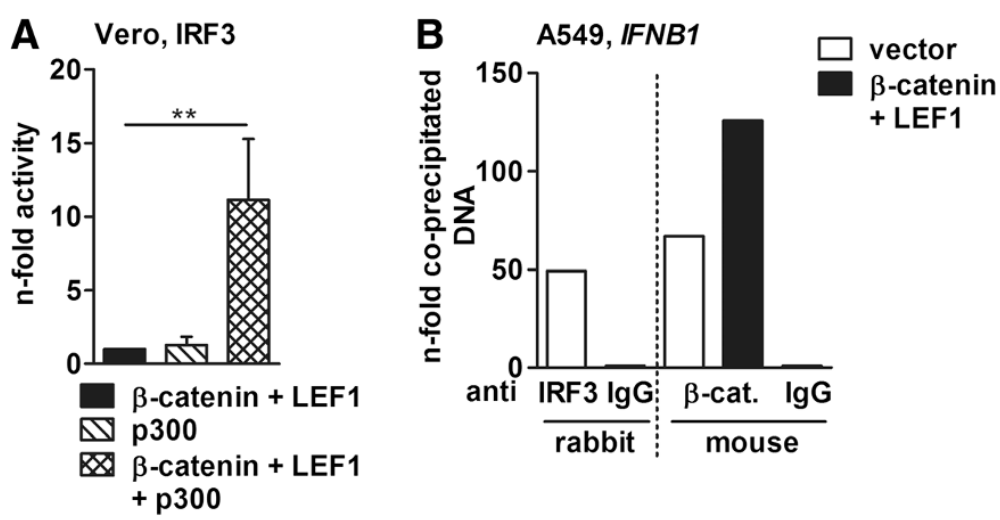

Figure $4 \beta$-catenin and LEF1 regulate IFN- $\beta$ promoter activity via IRF-PRD. (A) Vero cells were transfected with the reporter gene plasmid containing the IRF3-responsive elements of the IFN- $\beta$ enhanceosome along with indicated plasmids, and the reporter gene activity was measured $30 \mathrm{~h}$ later. The luciferase activity of $\beta$-catenin and LEF1-transfected cells was arbitrarily taken as unity. (B) A549 cells were transfected with empty vector or plasmids coding for $\beta$-catenin and LEF1 for $30 \mathrm{~h}$, and the interaction of cellular proteins with the DNA was analyzed by ChIP assays. The amount of amplified DNA in IRF3- and $\beta$-catenin-specific immunoprecipitates was quantified by qRT-PCR using primers specific for the promoter region of the IFNB1 gene. Values represent $\mathrm{n}$-folds of IgG controls. One of three independently repeated experiments is depicted as representative.

suppression of influenza virus replication, as seen in the presence of overexpressed ectopic or upregulated endogenous $\beta$-catenin (Figure 1 ) is based on the induction of IFN- $\beta$ that exerts antiviral control. To verify this role of $\beta$-catenin in antiviral defense, the degradationresistant mutant of the protein was overexpressed in Vero cells (Figure 5B) that harbor defective type I interferon genes and, therefore, cannot express endogenous IFN- $\alpha / \beta$ [42]. These cells were subsequently infected with vesicular stomatitis virus (VSV), a pathogen that is highly sensitive to IFN- $\beta[46,47]$. VSV is expected to propagate in control vector-transfected and in $\beta$-cateninoverexpressing cells with a similar intensity, given the hypothesis is supported. In contrast to the expectation, VSV replicated in $\beta$-catenin-overexpressing cells less efficiently than in control cells (Figure $5 \mathrm{C}$ ), suggesting that $\beta$-catenin might, in addition to IFN- $\beta$, positively regulate the expression of other proteins with antiviral potential.

Besides type I, also type III IFNs possess antiviral activity [48]. IFN- $\lambda$ is known to be involved in the induction of MxA expression [49] and was recently discovered as an important antiviral agent that reduced influenza A virus propagation [50]. Thus, one might speculate that $\beta$-catenin can enhance the $M X 1$ transcription shown in Figure $5 \mathrm{~A}$ indirectly, via induction of IFN- $\lambda$. However, a significant increase in IFN- $\lambda$ mRNA transcription was not detected in $\beta$-catenin- and LEF1-overexpressing cells (Additional file 1: Figure S3), suggesting that IFN- $\lambda$ is not responsible for the $\beta$-catenin-mediated induction of MxA mRNA and, consequently, the reduced VSV replication in Vero cells.

As mentioned previously, IFN- $\beta$ has no intrinsic antiviral activity, but induces the expression of genes that code for proteins with antiviral function via activation of the JAK/STAT pathway. To elucidate whether the $\beta$ catenin/LEF1 complex directly influences the transcription of interferon-stimulated genes, Vero cells were transfected with a luciferase reporter gene construct harboring interferon-stimulated response element (ISRE) motifs, and its activity was analyzed in the presence or absence of $\beta$-catenin and LEF1. Vero cells were chosen to avoid the effect of endogenous IFN- $\beta$ molecules on ISRE activity, the induction of which by the transcriptional complex has been shown above. Overexpression of $\beta$-catenin and LEF1 simultaneously stimulated ISREdriven transcription (Figure 5D, left panel). To mimic the cytokine response during virus infection, transfected Vero cells were additionally stimulated with $100 \mathrm{U} / \mathrm{ml}$ of recombinant IFN- $\beta$ (Figure $5 \mathrm{D}$, right panel). This resulted in an increase of reporter gene activity in control cells transfected with empty vector, thus, confirming the functionality of the reporter plasmid. IFN- $\beta$ stimulation of Vero cells transfected with $\beta$-catenin and LEF1 further enhanced the transcription driven by ISRE motifs, but the fold of induction was less to that in unstimulated cells, suggesting that only STAT transcription factors, but not the $\beta$-catenin/LEF1 transcription factor, were activated by interferon stimulation. A similar effect on luciferase activation was seen when $\gamma$-catenin instead of $\beta$-catenin was expressed in Vero cells (Figure 5E), thus, confirming that both catenins have the same antiviral molecular mechanism.

Zhang et al. showed that activated STAT1 recruits the $\mathrm{CBP} / \mathrm{p} 300$ co-activator to the transcriptional complex that binds to interferon-stimulated gene promoters [51]. Hence, considering the ability of $\beta$-catenin to bind CBP/ p300 as well, we asked whether these factors regulate 


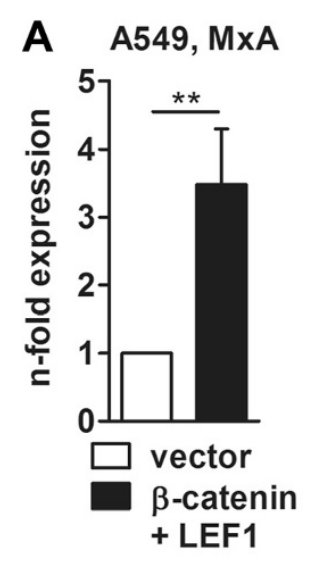

D Vero, ISRE

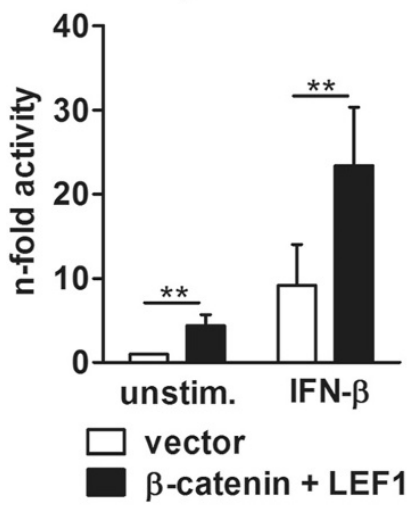

F Vero, ISRE

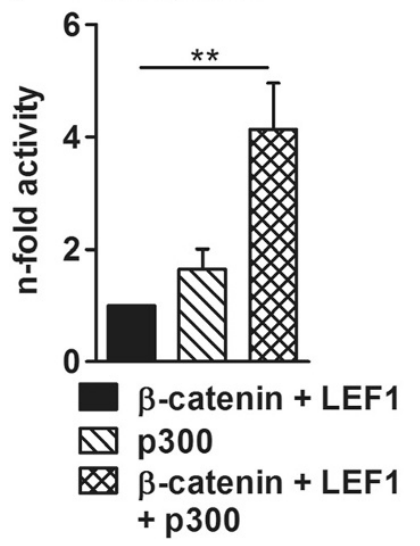

B

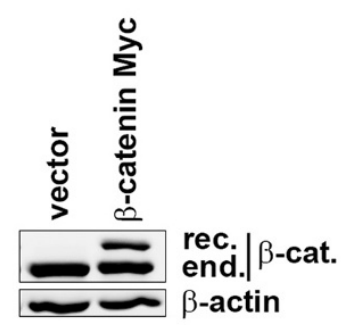

$\beta$-actin
C Vero, vsv

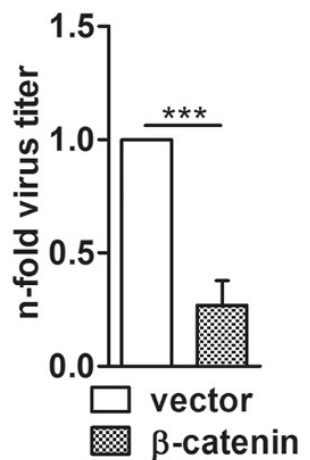

E Vero, ISRE

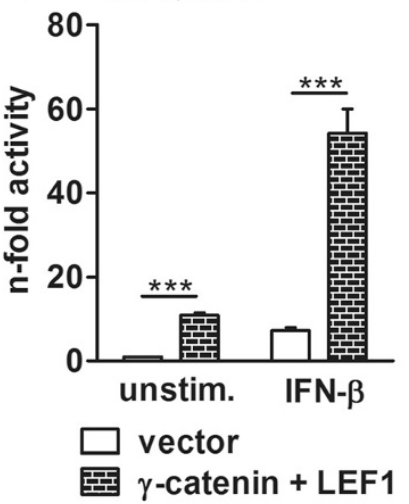

G A549, $M X 1$

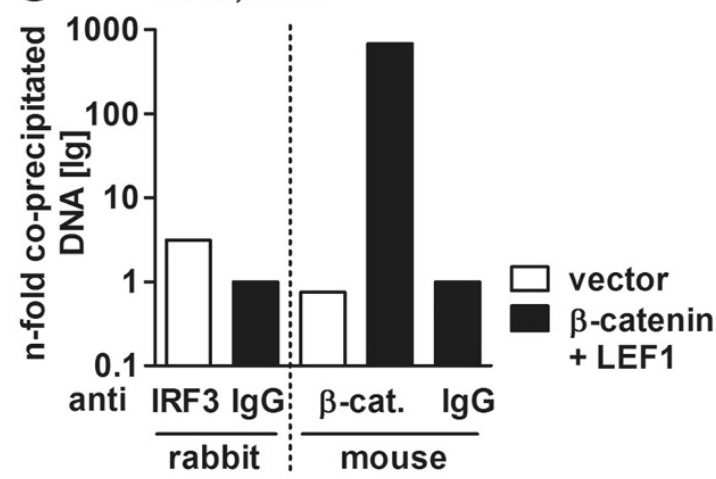

Figure 5 The ISG promoter activity is triggered by $\beta$ - and $\boldsymbol{\gamma}$-catenin. (A) A549 cells were transfected with $\beta$-catenin and LEF1 for $30 \mathrm{~h}$, and the mRNA level of the type I and type III IFN-dependent MXI gene was measured by qRT-PCR. The mRNA amount of empty vector-transfected cells was taken as unity. (B and C) Vero cells transfected for $24 \mathrm{~h}$ with indicated plasmids were infected with vesicular stomatitis virus (VSV) (MOI $=0.0001)$ for an additional $24 \mathrm{~h}$. Subsequently, the overexpression of $\beta$-catenin was confirmed by immunoblotting of corresponding RIPA lysates (B) and the propagation of VSV by standard plaque titration assay (C). (D and E) Vero cells were co-transfected with the ISRE luciferase reporter gene and plasmids coding for proteins indicated in column legends. After 24 hours, Vero cells were left unstimulated or treated with $100 \mathrm{U} / \mathrm{ml}$ IFN- $\beta$ for $8 \mathrm{~h}$. The $\mathrm{y}$-axis represents the relative reporter gene activity with luciferase activity of unstimulated, empty vector-transfected cells being set to one. (F) Vero cells were transfected with the ISRE luciferase reporter gene, and its activity in $\beta$-catenin- and LEF1-overexpressing cells was measured in the presence or absence of co-transfected p300. The luciferase activity of $\beta$-catenin and LEF1-transfected cells was arbitrarily taken as unity. (G) A549 cells were transfected with empty vector or plasmids coding for $\beta$-catenin and LEF1 for $30 \mathrm{~h}$, and the interaction of cellular proteins with the DNA was analyzed by ChIP assays using specific antibodies to IRF3 or $\beta$-catenin. The co-immunoprecipitated DNA was amplified by qRT-PCR using specific primers for the promoter region of the MX1 gene and is given as the $\mathrm{n}$-fold amount to the lgG control. Representative values from one of three repeated experiments are depicted. 
the transcription of ISRE in a cooperative manner. Coexpression of $\mathrm{p} 300$, in addition to $\beta$-catenin and LEF1, clearly showed an additive effect on the ISRE reporter gene activity in Vero cells. The luciferase activity was four times higher than in cells expressing $\beta$-catenin and LEF1 alone (Figure 5F). Thus, similar to IRF3-driven transcription of the IFNB1 gene, the $\beta$-catenin/LEF1 transcriptional complex supports the transcription of interferon-stimulated genes in concert with the general transcriptional co-activator p300.

To verify whether the effect of $\beta$-catenin on transcriptional activity of ISRE promoters is induced by binding to the promoter region, similar to that observed for the IFN- $\beta$ promoter, we analyzed if $\beta$-catenin can interact with the promoter region of ISGs by ChIP assays. Again, immunoprecipitation of IRF3, which is known to bind the ISRE motif of ISGs $[52,53]$, was used as positive control. As expected, IRF3 immunoprecipitates were positive for $M X 1$ promoter DNA, as detected by qRT-PCR, but more reasonable, the $\beta$-catenin immunoprecipitates were also positive for $M X 1$ promoter DNA, although only after overexpression of both $\beta$-catenin and LEF1 (Figure 5G).

In conclusion, the $\beta$-catenin-induced enhancement of ISRE promoter activity is mediated by binding of $\beta$ catenin to ISRE promoter DNA, similar to the IFN- $\beta$ induced transcription.

\section{Influenza $A$ virus inhibits the $\beta$-catenin-mediated transcriptional activation of LEF/TCF-dependent genes}

Regulation of gene transcription is a well-known function of $\beta$-catenin. To test whether IAV infection influences this function, A549 cells were transiently transfected with the catenin-LEF/TCF-dependent TopFlash reporter construct harboring LEF/TCF binding sites upstream of the thymidine kinase minimal promoter together with a plasmid encoding the phosphorylation-refractory $\beta$-catenin mutant. Subsequently, the cells were infected with the avian FPV strain (Figure 6A). As anticipated, the stabilized $\beta$-catenin protein strongly activated the transcription of the reporter gene. The effect was specific, as transfection of the FopFlash reporter vector containing mutated LEF/TCF binding sites was not activated by $\beta$-catenin (Additional file 1: Figure S4). However, in contrast to our expectation, IAV infection strongly repressed the $\beta$-catenin-dependent activation of the reporter gene (Figure 6A). Similar results were obtained when the human PR8 isolate was used (Additional file 1: Figure S5), indicating that the observed effect is not virus strain specific. Furthermore, accumulation of viral but not cellular RNA, which was transfected into A549 cells, was sufficient for repression of the $\beta$-catenin-dependent transcription (Figure 6B).
Influenza RNA molecules are sensed by cytoplasmic helicases, the RIG-I and melanoma differentiationassociated gene 5 (Mda5) [54], resulting in activation of several cellular signaling cascades that preferentially funnel into the transcriptional induction of the IFNB1 gene (Figure 6C) $[10,55,56]$. To identify the signaling cascades responsible for inactivation of the TopFlash reporter gene, the $\beta$-catenin-dependent activation of the promoter was analyzed in cells that also overexpress proteins representing different members of viral RNA-induced signaling pathways in addition to $\beta$-catenin. The results presented in Figure 6D clearly demonstrate that RIG-I- but not Mda5-mediated signaling was responsible for inhibition of the TopFlash reporter gene, as overexpression of active RIG-I or its downstream effector MAVS abolished $\beta$ catenin-induced promoter activity. Walking down the RIG-I/MAVS-dependent signaling cascades revealed that activation of the IKK2-p65 axis, but not of IRF3 or JNK and p38 branches, efficiently inhibited TopFlash reporter gene activity (Figure 6D). Western blot images shown in Figure $6 \mathrm{E}$ demonstrate the efficient overexpression of different molecules used for analysis of signaling pathways responsible for suppression of $\beta$-catenin function. Furthermore, treatment of cells with the IKK2-specific BAY inhibitor [57] prior to stimulation with viral RNA confirmed the involvement of the NF- $\mathrm{kB}$ cascade in $\beta$-catenin inactivation, as cells stimulated with the BAY inhibitor were unable to downregulate the TopFlash promoter activity (Figure 6F).

The NF-kB pathway is obligatorily activated after viral infection [58]. Given that activation of this pathway inhibits the transcription of LEF/TCF-dependent target genes, the $\beta$-catenin-mediated transcriptional support of the IFN- $\beta$ and ISRE-dependent genes should be inhibited on viral infection as well. To test this assumption, the luciferase activity of IRF3- and ISRE-dependent reporter genes was analyzed in the presence of an active or inactive IKK2 kinase. Results presented in Figures 6G and H show that both IRF3- and ISRE-dependent transcription were efficiently inhibited by overexpression of a functionally active IKK2 kinase, whereas the dominant-negative form of the IKK2 had rather an opposite or no effect.

Thus, the results presented here show that $\beta$-catenin supports the transcription of genes involved in regulation of the innate immune response to IAV infections, on the one hand, and that the functional activity of the $\beta$-catenin is at the same time suppressed by the IAV-mediated activation of the NF-kB pathway, on the other hand.

\section{Discussion}

Transcription and translation of viral RNA and proteins are strictly dependent on the host cell machinery [59]. Different cellular signaling cascades are known to be 


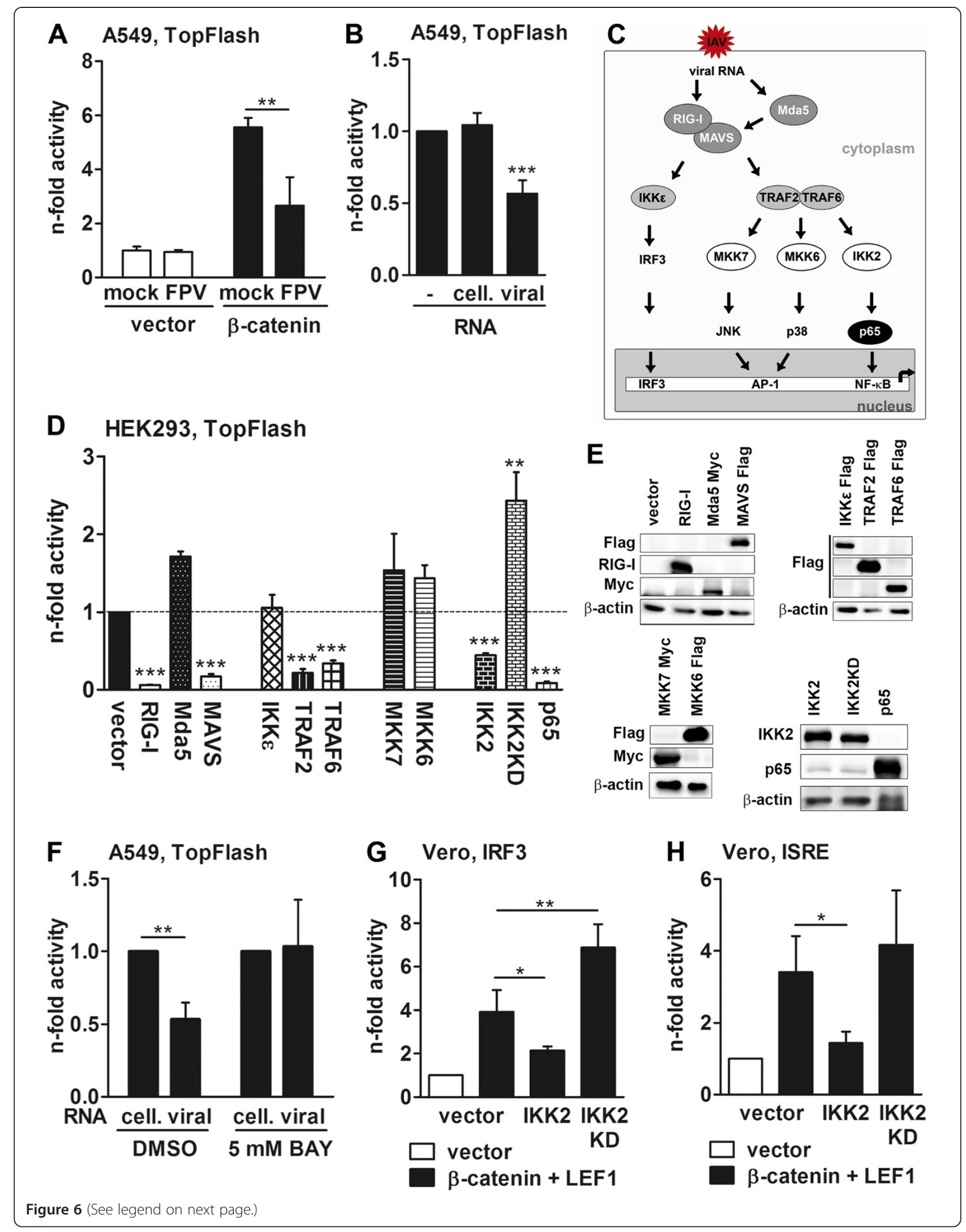


(See figure on previous page.)

Figure 6 IAV infection inhibits $\beta$-catenin-mediated transcriptional activation of LEF/TCF-dependent target genes. (A and B) A549 cells were transfected with the TopFlash reporter construct together with an empty vector or a plasmid coding for $\beta$-catenin. At $24 \mathrm{~h}$ post transfection, the cells were infected with FPV (MOI =5) or stimulated (via transfection) for an additional $8 \mathrm{~h}$ with $500 \mathrm{ng}$ of cellular or viral RNA or left untreated. Subsequently, the promoter activity was measured. The luciferase activity of mock-infected or unstimulated but empty vector-transfected cells was taken as unity. (C) A schedule of signaling cascades activated by IAV RNA is depicted (adapted from $[10,55,56])$. (D and E) HEK293 cells were transfected with the TopFlash reporter gene construct together with $\beta$-catenin and plasmids coding for the indicated proteins. At $30 \mathrm{~h}$ post transfection, the promoter activity was measured (D). The luciferase activity of $\beta$-catenin and empty vector-transfected cells was arbitrarily taken as unity. Overexpression of the recombinant proteins was analyzed by Western blotting. The $\beta$-actin immunoblots always served as loading controls (E). (F) A549 cells transfected with the TopFlash reporter plasmid together with $\beta$-catenin were stimulated with $5 \mathrm{mM}$ of BAY inhibitor or DMSO as control. At $16 \mathrm{~h}$ post stimulation, cells were transfected with $500 \mathrm{ng}$ cellular or viral RNA for an additional $8 \mathrm{~h}$ and the promoter activity was measured. The luciferase activity of cells stimulated with cellular RNA was always taken as unity. ( $\mathbf{G}$ and $\mathbf{H}$ ) Vero cells were transfected with reporter gene plasmids containing either the IRF3 responsive elements of the IFN- $\beta$ enhanceosome $\mathbf{( G )}$ or the ISRE motif $\mathbf{( H )}$ along with plasmids coding for proteins indicated in column legends. The promoter activity was measured $30 \mathrm{~h}$ post transfection. Luciferase activity of cells transfected with any vector control was arbitrarily taken as unity.

activated upon viral infection, like the MAP kinases ERK1/2, JNK and p38 or the classical NF-кB pathway, which support pro- or antiviral actions [34,60,61]. Furthermore, there are several cellular molecules identified that directly mediate antiviral activity, like different ISG proteins [12].

Ongoing interaction studies between influenza A virus proteins and cellular factors [62] as well as siRNA screens [63] suggest that Wnt signaling does not only control processes like cell differentiation, communication, apoptosis/ survival and proliferation but also plays a role during virus infections. In this study, the role of $\beta$-catenin, the intracellular content of which can be regulated for example by different factors including Wnt proteins, was elucidated in IAV-infected cells. We demonstrate here that $\beta$-catenin is involved in IAV replication and that its accumulation is sufficient to reduce virus propagation. Stimulation of human lung epithelial cells with either natural (Wnt3a) or artificial $(\mathrm{LiCl})$ agents that inactivate the GSK-3 $\alpha$ and $\beta$ kinases [36] and, thus, induce the cellular accumulation of $\beta$-catenin, reduced IAV replication. These results are consistent with the data presented by Kumar et al. where $\mathrm{LiCl}$ stimulation reduced HIV progression in peripheral blood mononuclear cells [64] and show the potential role of the canonical Wnt-signaling in anti-influenza response.

It is well known that $\beta$-catenin plays a dual role within the cell. On the one hand, it is part of adherens junctions at the cell membrane and, on the other hand, it interacts with LEF/TCF and acts as a transcription factor [19]. Due to the fact that the transcriptionally active $\beta$-catenin reduces viral propagation, we assumed that the effect is caused at the transcriptional level and not by mediating the association of viral RNPs to the actin cytoskeleton, like it was previously shown for parainfluenza virus infections [65]. The first and most potent wave of cellular innate immune response to IAV infection is mainly regulated at the transcriptional level. Here, we have shown that the activity of the IFN- $\beta$ enhanceosome is modulated by the $\beta$ catenin/LEF1 protein complex. The increased promoter activity was mediated via the IRF3-dependent PRDIII-I region but not by enhanced homodimerization of the interferon regulating factor 3 . Thus, the $\beta$-catenin/LEF1 complex does not act within the viral RNA-mediated IRF3 activation pathway but by direct interaction with the transcriptional complex. Recently Yang et al. showed that $\beta$ catenin can bind to IRF3 in HEK293 cells [44], and here we showed that the presence of the transcriptional cofactor p300 significantly raised the $\beta$-catenin-induced, IRF3-dependent promoter activity. The association of the general transcriptional co-factor $\mathrm{CBP} / \mathrm{p} 300$ with $\beta$-catenin or IRF3 was demonstrated in several independent studies, as well as the increase of $\beta$-catenin or IRF3 target gene transcription by recruiting CBP/p300 [43,45,66-68]. The results of our work further support and enhance these data by showing that the combined action of all three proteins is required for full activation of the IFN- $\beta$ promoter.

In addition to the enhancement of IFN- $\beta$ expression, we show here that $\beta$-catenin and LEF1 also activate genes of the IFN induced wave of cellular innate immune response to influenza virus infection, namely the transcription of interferon-stimulated genes, whose products directly inhibit transcription and translation of viral RNA and proteins. The fact that the $\beta$-catenin/LEF1 protein complex regulates both IFN- $\beta$ and ISG promoter activity shows that it possess a biphasic antiviral action. In both cases, $\beta$ catenin exercised its activity by binding to appropriate DNA promoter regions. This binding is most likely indirect, as $\beta$-catenin itself has no DNA-binding domains and there are no classical LEF/TCF binding sites [69] in the promoter regions of either IFNB1 or $M X 1$ gene (Additional file 2: Figure S6). It is conceivable that IRF3 is the primary DNA-binding protein and the transcriptional co-activator p300 is the common link between IRF3 and $\beta$-catenin/LEF1 protein complex, as co-expression of p300 significantly enhanced the $\beta$-catenin/LEF1-mediated transcriptional activity of both IFN- $\beta$ and ISG promoters. 
Cellular $\gamma$-catenin is the close homologue of $\beta$-catenin and also possesses a dual function, controlling cell-cell adhesion at the membrane [31] and gene transcription in the nucleus [32]. Both catenins bind to cadherin receptors and regulate the activity of common target genes in concert with LEF1 as transcriptional complex [32,33]. Our results provide further functional significance for $\beta$ - and $\gamma$ catenin and underscore their redundancy. Indeed, knockdown of $\beta$-catenin by specific RNAi resulted in prompt enhancement of $\gamma$-catenin expression, and we showed for the first time that both catenins efficiently enhanced the cellular innate immune response to influenza A viruses by promoting IFN- $\beta$ and ISG expression.

Recently, it was demonstrated that GSK-3 $\beta$ is inactivated upon influenza A virus infection through phosphorylation at Ser9 by kinases via the phosphatidylinositol 3-kinase (PI3K)/Akt pathway [30]. Here, we showed that $\beta$-catenin accumulates in the nucleus after IAV infection. These data suggest that the $\beta$-catenin signaling is influenced by virus infection. Lately, Zhu et al. [70] showed that during Sendai virus infections, $\beta$-catenin is deacetylated by PKC-activated HDAC6, which results in nuclear translocation of $\beta$-catenin and enhanced IRF3-dependent expression of interferon responsive genes. We showed here that $\beta$-catenin supports the IRF3-dependent transcription of genes responsible for the cellular innate immune response, the IFN- $\beta$ and ISGs. In contrast to these results, Baril and co-workers reported that Wnt signaling does not support interferon induction after Sendai virus infection and that Wnt9B and Wnt2B but not the Wnt3a efficiently reduces IFN expression [71]. Although the reason for the discrepancy between these data and results discussed above is not clear yet, different posttranslational modifications of the $\beta$-catenin protein due to the different Wnt stimuli as well as to different viruses and cell types used might be a plausible explanation.

Altogether, these results indicate that $\beta$-catenin is involved in the cellular defense against different virus types, although in a different way, and, therefore, represents an important antiviral molecule. Interestingly, influenza viruses counteract the antiviral potency of $\beta$-catenin by inhibiting its transcriptional activity. While in the case of human cytomegalovirus infection, $\beta$-catenin inhibition was mediated by newly synthesized viral proteins [72], the IAV inhibition of $\beta$-catenin was induced through accumulation of viral RNA and subsequent activation of the NF- $k B$ signaling cascade. Though the exact molecular mechanism of the p65-induced inhibition of $\beta$-catenin-dependent transcription is still unknown, it is very likely that binding of the NF- $\mathrm{B}$ p 65 transcription factor to $\beta$-catenin is responsible for the inhibition of the latter, as the association of p65 with $\beta$-catenin [73-75] and the inhibitory effect of the protein complex onto the TopFlash activity has been reported previously [74-76]. Whether the $\beta$-catenin-p65 interaction also regulates the NF- $\mathrm{kB}$ activity is still controversy discussed in the literature $[73,75,76]$, nonetheless, no significant differences in NF- $\mathrm{kB}$ promoter activity on overexpression of $\beta$-catenin and LEF1 were observed in this study.

\section{Conclusion}

We described in this study the anti-influenza potential of the transcriptionally active $\beta$ - and $\gamma$-catenin. We showed that they comprise an antiviral activity by a direct support of (i) the transcription of the INFB1 gene, the first wave of the cellular innate immune response and (ii) the transcription of the interferon-stimulated genes. However, upon IAV infection, $\beta$-catenin-dependent transcription is inhibited via the RIG-I/NF-KB signaling cascade that is activated by accumulated viral RNA.

\section{Materials and methods}

\section{Cell culture and influenza A virus infection}

The human alveolar epithelial (A549), colorectal cancer (SW480), embryonic kidney (HEK293) and green monkey epithelial (Vero) cells were grown in Dulbecco's minimal essential medium (D-MEM) and Madin-Darby canine kidney (MDCKII) cells in minimal essential medium (MEM) supplemented with $10 \%$ bovine fetal serum (Biochrome).

The human influenza virus strain A/Puerto Rico/8/34 (PR8, H1N1) was originally obtained from T. Wolff (Robert-Koch Institute, Berlin, Germany), and the avian influenza virus strain A/FPV/Bratislava/79 (FPV, H7N7) was used with kind permission of S. Pleschka (Institute of Virology, Giessen, Germany); both were propagated in MDCKII cells. The vesicular stomatitis virus strain Indiana (VSV) was a gift from T. Wolff (Robert-Koch Institute, Berlin, Germany) and was propagated in Vero cells. For infection, cells were washed with PBS and incubated with viruses diluted in PBS containing $0.2 \%$ bovine albumin, 100 $\mathrm{U} / \mathrm{ml}$ penicillin and $0.1 \mathrm{mg} / \mathrm{ml}$ streptomycin (PAA) for $30 \mathrm{~min}$ at $37^{\circ} \mathrm{C}$ with indicated MOIs (multiplicity of infection) or without virus particles (mock infection) as a control. After washing, the virus solution was replaced with growth medium containing $0.2 \%$ bovine albumin and antibiotics, and cells were incubated for the indicated times. To quantify virus propagation, cell supernatants were taken $24 \mathrm{~h}$ post infection and analyzed in standard plaque titration assays as described previously [77]. Recombinant human IFN- $\beta$ was purchased from PBL Interferon Source, BAY11-7085 from Sigma-Aldrich, recombinant human Wnt3a from R\&D Systems and lithium chloride ( $\mathrm{LiCl}$ ) was obtained from Carl Roth $\mathrm{GmbH}$.

\section{CHIP analysis}

For analysis of protein-DNA interactions, the Magna ChIP A Kit purchased from Millipore was used according to the 
manufacturer's instructions. For each reaction, $5 \mu \mathrm{g}$ of a specific antibody or the control serum were utilized. Immunoprecipitated DNA was quantified by qRT-PCR with primers specific for the promoter region of the investigated gene. The amount of immunoprecipitated DNA in each sample was calculated in comparison to the total DNA per sample. Each yielded value was then normalized to IgG controls. The primers were:

IFNB1 fw 5'-GAATAGGAAAACTGAAAGGGAGA-3', IFNB1 rev 5' -GTGTCGCCTACTACCTGTTGTG-3'; $M X 1 \mathrm{fw} 5^{\prime}$-CCCCTGGATTCTGAAGTCTGA- ${ }^{\prime}$, MX1 rev 5'-TTTCCCGGACAATTCAGTTTC-3'.

\section{pppRNA generation, RNA isolation and quantitative real time-PCR (qRT-PCR)}

The 5' -triphosphate modified RNA (pppRNA) was generated as described previously [78]. For production of viral RNA, A549 cells were either mock- or PR8-infected with an MOI of 5 . Then, $8 \mathrm{~h}$ post infection the total RNA was isolated using the RNeasy Kit (Qiagen). RNA isolated from mock-infected cells was used as a control and referred to as cellular RNA, while RNA isolated from IAV-infected cells was termed viral RNA.

For synthesis of cDNA, $1 \mu \mathrm{g}$ of total RNA, isolated from cells using the RNeasy kit (Qiagen), were reversetranscribed with RevertAID polymerase (Fermentas) according to the manufacturer's instructions.

The qRT-PCR analysis of obtained cDNA probes was performed with LightCycler 480 (Roche) and $2 \times$ SYBR Green Brilliant III Master Mix (Agilent Technologies/ Stratagene). For that, $0.5 \mu \mathrm{l}$ of synthesized cDNA was mixed with $4 \mu \mathrm{l}$ of $2 \times$ SYBR Green Brilliant Master Mix and $0.6 \mu \mathrm{l}$ of each primer $[10 \mathrm{pmol} / \mu \mathrm{l}]$ and brought up to a total volume of $12 \mu \mathrm{l}$ with RNase free water. The following primer pairs were used for mRNA analysis: human GAPDH: 5'-GCAAATTTCCATGGCACCGT$3^{\prime}$ and 5'-GCCCCACTTGATTTTGGAGG-3'; human MxA: 5' -GTTTCCGAAGTGGACATCGCA-3' and 5' GAAGGGCAACTCCTGACAGT-3'; human IFN- $\lambda$ : 5'-GTGCTGGTGACTTTGGTGCTA-3' and 5' -GAGAA GCCTCAGGTCCCAAT-3'; mouse $\beta$-catenin: 5 '-ATGG CTTGGAATGAGACTGC-3' and 5'-CTCCATCATAGG GTCCATCC-3'; mouse LEF1: 5'-CCCGTCAGATGTC AACTCCA-3' and 5'-CGTGATGGGATAAACAGGCT$3^{\prime}$. mRNA amounts were normalized to GAPDH, and relative changes in expression levels ( $\mathrm{n}$-fold) were calculated according to the $2^{-\Delta \Delta \mathrm{CT}}$ method [79].

\section{Transfection and reporter gene assays}

For siRNA-based knockdown, $5 \times 10^{5} \mathrm{SW} 480$ cells were transfected in suspension with $150 \mathrm{ng}$ of $\beta$-catenin siRNA (5'-CTCGGGATGTTCACAACCGAA-3') or control siRNA (5' -UUCUCCGAACGUGUCACGU-3')
(Qiagen) using the HiPerfect (Qiagen) transfection reagent. For analysis of mRNA expression, A549 cells $\left(5 \times 10^{5}\right.$ per 6-well dish) were transfected with X-treme Gene HP (Roche) following the manufacturer's instructions. For reporter gene assays, A549 or Vero cells $\left(2 \times 10^{5}\right.$ or $1.5 \times 10^{5}$ per 12-well dish) were transfected with various combinations of protein-expressing plasmids along with reporter gene constructs using Lipofectamine 2000 (Invitrogen). HEK293 cells $\left(2 \times 10^{5}\right.$ per 12-well dish) were transfected with polyethylenimine (PEI) in a 1:3 ratio $(1 \mu \mathrm{g}$ DNA: $3 \mu \mathrm{l}$ PEI $[1 \mathrm{mg} / \mathrm{ml}])$. Typically $0.3 \mu \mathrm{g}$ of luciferase reporter plasmid DNA was co-transfected with $0.5 \mu \mathrm{g}$ of each expression plasmid encoding either empty vector or indicated proteins which were: pEGFP RIG-I Card (gift of F. Weber, University Hospital Freiburg, Germany), pcDNA3 Flag MAVS [80], pEF1 Myc-His Mda5 (gift of T. Wolff, RobertKoch Institute, Berlin, Germany), pEFP Flag IKKe, pRK Flag TRAF2, pFlag TRAF6, pcDNA3 MKK6 Flag (given by R. Davis, Medical School, UMass), pCS3 + MT MKK7 (gift of M. Kracht, Rudolf-Buchheim-Institute of Pharmacology, University of Giessen, Germany), pEGFP IRF3DD, pcDNA3 IKK2 and pcDNA3 IKK2KD (plasmid collection of the IMV, Münster, Germany), pcDNA3 $\beta$-catenin S33A 6xMyc (murine) and pCG murine LEF1 HA (murine) [35], pFC $\Delta$ MEKK1 [81] or pCMV p300 HA (given by K.-H. Klempnauer; Institute of Biochemistry, Münster, Germany). The pcDNA3 p65 expression plasmid was generated via cloning the PCR amplicon of pGal4 p65 [82] into BamHI/ NotI restriction sites of the pcDNA3.1 vector. The pcDNA3 6xMyc $\gamma$-catenin expression plasmid was obtained by recloning the plakoglobin cDNA from the pGAD424 plakoglobin [35] plasmid into the pcDNA3 6xMyc vector.

The used luciferase reporter gene constructs were described previously: pTATA IFN $\beta$ luc, pTATA-4xIRF3 luc and NF-kB-driven pGL3-5xNF-kB luc [78], AP1-driven pB4xAP1/Etsluc reporter gene construct [81], pTA ISRE luc (Clontech Laboratories), pTK-TopFlash and pTKFopFlash [35]. Luciferase activities were measured $30 \mathrm{~h}$ post transfection using the luciferase protocol as described in [83] and the MicroLumatPlus LB 96 V luminometer (Berthold Technologies). The relative light units (RLUs) were normalized to protein concentrations, determined using the Bradford dye [84], and given as the $\mathrm{n}$-fold activity of the indicated control.

Total amounts of transfected DNA per cell dish varied depending on the experimental protocol, but the total DNA content per dish within the experiment was kept constant by adding the appropriate amount of empty expression vector. Each transfection was carried out in duplicate or triplicate.

\section{Protein lysates and Western blot analysis}

Cells were washed with PBS and lysed in RIPA buffer (25 mM Tris/HCl pH 8, $137 \mathrm{mM} \mathrm{NaCl}, 10 \%$ glycerol, 
0.1\% SDS, 0.5\% DOC, 1\% NP-40, 2 mM EDTA, 1 mM sodium vanadate, $5 \mu \mathrm{g} / \mathrm{ml}$ leupeptin, $5 \mu \mathrm{g} / \mathrm{ml}$ aprotinin and $200 \mu \mathrm{M}$ pefablock). The lysates were cleared by centrifugation at $10,000 \mathrm{~g}$ for $10 \mathrm{~min}$ at $4^{\circ} \mathrm{C}$. Afterwards, the protein amount was determined by BCA (bicinchoninic acid) protein reagent assay (Thermo Fisher Scientific), and $20 \mu \mathrm{g}$ of total protein lysates was resolved by discontinuous SDS-PAGE. To analyze the IRF3 dimerization, a native PAGE was performed as described previously [85]. Briefly, $2 \times 10^{6}$ cells were scraped into $50 \mu \mathrm{l}$ of lysis buffer (50 nM Tris-HCl pH 8, 1\% NP-40, $150 \mathrm{mM} \mathrm{NaCl}$, $100 \mu \mathrm{g} / \mathrm{ml}$ leupeptin and $5 \mathrm{mM}$ sodium vanadate), and supernatants were cleared by centrifugation in a standard table-top centrifuge at maximum speed at $4^{\circ} \mathrm{C}$. Equal protein amounts in sample buffer $(125 \mathrm{nM}$ Tris- $\mathrm{HCl} \mathrm{pH} \mathrm{8,}$ $30 \%$ glycerol, bromphenol blue) were separated on a $7.5 \%$ polyacrylamide gel with a two-buffer system (upper chamber buffer: 25 mM Tris-HCl pH 8.4, $192 \mathrm{mM}$ glycine, and $1 \%$ sodium deoxycholate; lower chamber buffer: $25 \mathrm{mM}$ Tris- $\mathrm{HCl} \mathrm{pH} 8.4$ and $192 \mathrm{mM}$ glycine) at constant $20 \mathrm{~mA}$ on ice. Before blotting of proteins onto nitrocellulose membranes, the gel was soaked in SDS-PAGE running buffer (25 mM Tris- $\mathrm{HCl} \mathrm{pH} \mathrm{8.4,} 250 \mathrm{mM}$ glycine and $0.1 \% \mathrm{SDS}$ ) for $30 \mathrm{~min}$. After electroblotting onto nitrocellulose membranes, the specific proteins were detected by Western blot analysis with appropriate antibodies using the ECL detection system. The used antibodies were: mAb anti- $\beta$-catenin clone 14 and $\mathrm{mAb}$ anti- $\gamma-$ catenin (BD Transduction Laboratories), mAb anti-HA (clone 12CA5) and mAb anti-myc (clone 9E10) (ATCC Cell Biology Collection), pAb anti-influenza PB1 VK20, mAb antiinfluenza NS1 clone NS1 23-1, pAb anti-IKK $\alpha / \beta$ and pAb anti-IRF3 (Santa Cruz Biotechnology), mAb anti-p65, $\mathrm{mAb}$ anti-GSK-3 $\beta$ and pAb anti-p-GSK-3 $\beta$ Ser9 (Cell Signaling), mAb anti-RIG-I (Enzo Life Sciences), mAb anti-Lamin $C$ (Abcam) mAb anti-Flag, mAb anti- $\beta$ actin and $\mathrm{mAb}$ anti- $\alpha$-tubulin (Sigma-Aldrich). Antiserum against viral PB2 protein was a kind gift from Dr. E. Fodor (Sir William Dunn School of Pathology, Oxford, UK [86]) The secondary antibodies were obtained from Jackson Immunoresearch (donkey anti-goat IgG-POX and goat anti-mouse IgG-POX) or Biorad technologies (goat anti-rabbit IgG-HRP).

Preparation of cytosolic and nuclear fractions was performed as described in [87]. Briefly, $2.5 \times 10^{6}$ HEK293 cells were treated as indicated in the figure legend, washed twice with ice-cold PBS, scrapped off and harvested by centrifugation $\left(5 \mathrm{~min} 650 \mathrm{~g}\right.$ at $4^{\circ} \mathrm{C}$ ). Cell pellets were lysed in $1 \mathrm{ml}$ Roeder A buffer (10 mM HEPES $\mathrm{pH} 7.9,1.5 \mathrm{mM} \mathrm{MgCl}_{2}, 10 \mathrm{mM} \mathrm{KCl}$ supplemented with $0.5 \mathrm{mM}$ DTT, $1 \mathrm{mM}$ sodium vanadate, $0.2 \mathrm{mM}$ pefablock, $5 \mathrm{mg} / \mathrm{ml}$ leupeptin, and $5 \mathrm{mg} / \mathrm{ml}$ aprotinin) and incubated on ice for $10 \mathrm{~min}$. Then, NP-40 was added to a final concentration of $0.3 \%$ and cell lysates were mixed and incubated for an additional 10 min on ice. Next, nuclei were sedimented by centrifugation $(10 \mathrm{~min}$ at $2650 \mathrm{~g}$ and $4^{\circ} \mathrm{C}$ ) and the supernatant was collected (referred as cytoplasmic fraction). The pellet was washed with $1 \mathrm{ml}$ Roeder A buffer and subsequently resuspended in $300 \mu \mathrm{l}$ of Roeder C buffer (25\% (v/v) glycerol, $0.3 \mathrm{M} \mathrm{NaCl}, 1.5 \mathrm{mM} \mathrm{MgCl} 2,20 \mathrm{mM}$ HEPES pH 7.9 supplemented with $0.5 \mathrm{mM}$ DTT, $1 \mathrm{mM}$ sodium vanadate, $0.2 \mathrm{mM}$ pefablock, $5 \mathrm{mg} / \mathrm{ml}$ leupeptin, and $5 \mathrm{mg} / \mathrm{ml}$ aprotinin). After incubation for over-night in an overhead rotator at $4^{\circ} \mathrm{C}$ the nuclear fraction was clarified by centrifugation (30 $\mathrm{min}, 20000 \mathrm{~g}$ at $4^{\circ} \mathrm{C}$ ) and used for SDS-PAGE and Western blotting.

\section{Software}

For detection of signals, quantification, evaluation or illustration of the results, the following software was used: XStella_2.14, WinGlow-Control Programm LB96V, Aida Image Analyser v.4.21, Excel (Microsoft office 2010), Adobe Photoshop CS3 and GraphPad Prism 5.

\section{Statistical analysis}

Statistical significance between samples was determined using the homoscedastic Student's $t$-test in two-tailed distribution. Values of $* \mathrm{p} \leq 0.05, * \mathrm{p} \leq 0.01$ and ${ }^{* * * *} \mathrm{p} \leq$ 0.001 are indicated. If no specification is denoted in the legends, mean values \pm SD from at least three independent experiments are depicted. Some figures display mean values from one representative out of three independent experiments. This is due to variations in the basal promoter activity or viral propagation between the different repeats while the findings are comparable. In these cases, mean values \pm SD are calculated from three biological replicates.

\section{Additional files}

\footnotetext{
Additional file 1: Figure S1. IAV infection results in phosphorylation of GSK-33. (A and B) A549 cells were infected with influenza A/FPV/Bratislava/ 79 (FPV, H7N7) or influenza A/Puerto Rico/8/34 (H1N1) (MOI = 5) for indicated times. RIPA lysates were analyzed for designated proteins. Infection was verified by PB1 and NS1 and equal protein loads by GSK-3 $\beta$ and $\beta$-actin. Figure S2. IRF3 dimerization is independent on $\beta$-catenin and LEF1 overexpression. A549 cells overexpressing $\beta$-catenin and/or LEF1 were stimulated with $1 \mu \mathrm{g}$ of cellular or viral RNA for $4 \mathrm{~h}$ and IRF3 dimerization was analyzed by non-denaturing electrophoresis and Western blotting. Equal protein loads were verified by $\beta$-actin immunoblotting. Figure S3. Analysis of IFN- $\lambda$ mRNA expression in $\beta$-catenin- and LEF1-overexpressing cells. A549 cells were transfected with $\beta$-catenin and LEF1 for $30 \mathrm{~h}$, and the mRNA level of the IFNL1 gene was measured by qRT-PCR. Figure S4. Comparison of FopFlash and TopFlash promoter activity. A549 cells were transfected with indicated reporter constructs together with the empty vector or $\beta$-catenin. $24 \mathrm{~h}$ later, cells were stimulated with $500 \mathrm{ng}$ of cellular or viral RNA for an additional $8 \mathrm{~h}$ and the promoter activity was measured. The luciferase activity of cellular RNA-stimulated and with empty vector-transfected cells was taken as unity. A representative image out of three independent experiments is shown. Figure S5. Regulation of $\beta$-catenin-dependent transcription upon PR8 infection. A549 cells were
} 
transfected with the TopFlash reporter construct and empty vector or a plasmid encoding $\beta$-catenin. $24 \mathrm{~h}$ post transfection, the cells were infected with PR8 $(\mathrm{MOI}=5)$ for an additional $8 \mathrm{~h}$, and the promoter activity was measured. A representative image out of three independent experiments is shown. Table S1. Detection of recombinant $\beta$-catenin and LEF1 by qRT-PCR after transient transfection of A549 cells. The human GAPDH mRNA level was used as control.

Additional file 2: Figure S6. Overview of IFNB1 or MX1 promoter regions with binding sites of potential transcription factors. Sequences of IFNB1 (chr9:21077842-21078441) (A) and MX1 (chr21:42791953-42792552) (B) promoter regions that have been amplified for ChIP assay analysis are shown. The potential transcription factors and their binding sites were verified using the bioinformatics tool NSITE of Softberry Inc. Nucleotides are numbered beginning at transcription sites. The arrows denote the direction of transcription.

\section{Abbreviations}

AP-1: Activator protein-1; CBP: CREB binding protein; FPV: Fowl plaque virus A/FPV/Bratislava/79 (H7N7); GSK: Glycogen synthase kinase; IAV: Influenza A virus; IFN: Interferon; IKK: I-kappa-B kinase; IRF: Interferon regulatory factor; ISG: Interferon-stimulated gene; ISRE: Interferon-stimulated response element; LEF: Lymphoid enhancer factor; LiCl: Lithium chloride; MxA: Myxovirus resistance gene A; MAVS: Mitochondrial antiviral-signaling protein; MOI: Multiplicity of infection; NF-KB: Nuclear factor kappa-light-chain-enhancer of activated B-cells; p.i: Post infection; PR8: A/Puerto Rico/8/34 (H1N1); RIG: Retinoic acid inducible gene; STAT: Signal transducers and activators of transcription; TBK-1: TANK-binding kinase 1; TCF: T-cell factor; VSV: Vesicular stomatitis virus.

\section{Competing interests}

The authors declare that they have no competing interests.

\section{Authors' contributions}

AH performed experiments, analyzed the data and designed the Figures. YB and $\mathrm{CN}$ were also involved in performing experiments and assisted with analyzing and interpreting data. AH, SL and VW designed the research, analyzed the data and wrote the manuscript. All authors read and approved the final manuscript.

\section{Acknowledgements}

This work was supported by IZKF (Interdisciplinary Center for Clinical Research) Muenster Grants Wix2/005/10 and Lud2/017/13.

Received: 25 October 2013 Accepted: 15 April 2014

Published: 26 April 2014

\section{References}

1. Cheung TK, Poon LL: Biology of influenza A virus. Ann N Y Acad Sci 2007, 1102:1-25.

2. Jagger BW, Wise HM, Kash JC, Walters KA, Wills NM, Xiao YL, Dunfee RL, Schwartzman LM, Ozinsky A, Bell GL, Dalton RM, Lo A, Efstathiou S, Atkins JF, Firth AE, Taubenberger JK, Digard P: An overlapping protein-coding region in influenza $A$ virus segment 3 modulates the host response. Science 2012, 337:199-204.

3. Wise HM, Foeglein A, Sun J, Dalton RM, Patel S, Howard W, Anderson EC, Barclay WS, Digard P: A complicated message: identification of a novel PB1-related protein translated from influenza A virus segment 2 mRNA. J Virol 2009, 83:8021-8031.

4. Wise HM, Hutchinson EC, Jagger BW, Stuart AD, Kang ZH, Robb N, Schwartzman LM, Kash JC, Fodor E, Firth AE, Gog JR, Taubenberger JK, Digard P: Identification of a novel splice variant form of the influenza A virus $\mathrm{M} 2$ ion channel with an antigenically distinct ectodomain. PLoS Pathog 2012, 8: 1002998.

5. Ehrhardt C, Seyer R, Hrincius ER, Eierhoff T, Wolff T, Ludwig S: Interplay between influenza $A$ virus and the innate immune signaling. Microbes Infect 2010, 12:81-87.

6. Ludwig S, Pleschka S, Planz O, Wolff T: Ringing the alarm bells: signalling and apoptosis in influenza virus infected cells. Cell Microbiol 2006, 8:375-386.
7. Ludwig S: Exploited defense: how influenza viruses take advantage of antiviral signaling responses. Futur Virol 2007, 2:91-100.

8. Hornung V, Ellegast J, Kim S, Brzozka K, Jung A, Kato H, Poeck H, Akira S, Conzelmann KK, Schlee M, Endres S, Hartmann G: $5^{\prime}$-triphosphate RNA is the ligand for RIG-I. Science 2006, 314:994-997.

9. Pichlmair A, Schulz O, Tan CP, Naslund TI, Liljestrom P, Weber F, Reis e Sousa C: RIG-I-mediated antiviral responses to single-stranded RNA bearing 5'-phosphates. Science 2006, 314:997-1001.

10. Randall RE, Goodbourn S: Interferons and viruses: an interplay between induction, signalling, antiviral responses and virus countermeasures. J Gen Virol 2008, 89:1-47.

11. Hale BG, Albrecht RA, Garcia-Sastre A: Innate immune evasion strategies of influenza viruses. Future Microbiol 2010, 5:23-41.

12. Schmolke M, Garcia-Sastre A: Evasion of innate and adaptive immune responses by influenza a virus. Cell Microbiol 2010, 12:873-880.

13. Turan K, Mibayashi M, Sugiyama K, Saito S, Numajiri A, Nagata K: Nuclear MxA proteins form a complex with influenza virus NP and inhibit the transcription of the engineered influenza virus genome. Nucleic Acids Res 2004, 32:643-652.

14. Rebouillat D, Hovanessian AG: The human 2',5'-oligoadenylate synthetase family: interferon-induced proteins with unique enzymatic properties. J Interferon Cytokine Res 1999, 19:295-308.

15. Garcia MA, Gil J, Ventoso I, Guerra S, Domingo E, Rivas C, Esteban M: Impact of protein kinase PKR in cell biology: from antiviral to antiproliferative action. Microbiol Mol Biol Rev 2006, 70:1032-1060.

16. Graham TA, Weaver C, Mao F, Kimelman D, Xu W: Crystal structure of a beta-catenin/Tcf complex. Cell 2000, 103:885-896.

17. Huber AH, Weis WI: The structure of the beta-catenin/E-cadherin complex and the molecular basis of diverse ligand recognition by beta-catenin. Cell 2001, 105:391-402.

18. Spink KE, Polakis $P$, Weis WI: Structural basis of the axin-adenomatous polyposis coli interaction. EMBO J 2000, 19:2270-2279.

19. Brembeck FH, Rosario M, Birchmeier W: Balancing cell adhesion and Wnt signaling, the key role of beta-catenin. Curr Opin Genet Dev 2006, 16:51-59.

20. Ding Y, Dale T: Wnt signal transduction: kinase cogs in a nano-machine? Trends Biochem Sci 2002, 27:327-329.

21. Aberle H, Bauer A, Stappert J, Kispert A, Kemler R: beta-catenin is a target for the ubiquitin-proteasome pathway. EMBO J 1997, 16:3797-3804.

22. Tamai K, Semenov M, Kato Y, Spokony R, Liu C, Katsuyama Y, Hess F, SaintJeannet JP, He X: LDL-receptor-related proteins in Wnt signal transduction. Nature 2000, 407:530-535.

23. Zeng $X$, Huang H, Tamai K, Zhang X, Harada Y, Yokota C, Almeida K, Wang J, Doble B, Woodgett J, Wynshaw-Boris A, Hsieh JC, He X: Initiation of Wnt signaling: control of Wnt coreceptor Lrp6 phosphorylation/activation via frizzled, dishevelled and axin functions. Development 2008, 135:367-375.

24. Shi CS, Huang NN, Harrison K, Han SB, Kehrl JH: The mitogen-activated protein kinase kinase kinase kinase GCKR positively regulates canonical and noncanonical Wnt signaling in B lymphocytes. Mol Cell Biol 2006, 26:6511-6521.

25. Shtutman M, Zhurinsky J, Simcha I, Albanese C, D'Amico M, Pestell R Ben-Ze'ev A: The cyclin D1 gene is a target of the beta-catenin/LEF-1 pathway. Proc Natl Acad Sci U S A 1999, 96:5522-5527.

26. Tetsu O, McCormick F: Beta-catenin regulates expression of cyclin D1 in colon carcinoma cells. Nature 1999, 398:422-426.

27. He TC, Sparks AB, Rago C, Hermeking H, Zawel L, da Costa LT, Morin PJ, Vogelstein B, Kinzler KW: Identification of c-MYC as a target of the APC pathway. Science 1998, 281:1509-1512.

28. Cross DA, Alessi DR, Vandenheede JR, McDowell HE, Hundal HS, Cohen P. The inhibition of glycogen synthase kinase-3 by insulin or insulin-like growth factor 1 in the rat skeletal muscle cell line L 6 is blocked by wortmannin, but not by rapamycin: evidence that wortmannin blocks activation of the mitogen-activated protein kinase pathway in L6 cells between Ras and Raf. Biochem J 1994, 303(Pt 1):21-26.

29. Sutherland $C$, Leighton IA, Cohen P: Inactivation of glycogen synthase kinase-3 beta by phosphorylation: new kinase connections in insulin and growth-factor signalling. Biochem J 1993, 296(Pt 1):15-19.

30. Ehrhardt C, Wolff T, Pleschka S, Planz O, Beermann W, Bode JG, Schmolke M, Ludwig S: Influenza A virus NS1 protein activates the PI3K/Akt pathway to mediate antiapoptotic signaling responses. J Virol 2007, 81:3058-3067.

31. Rubinfeld B, Souza B, Albert I, Munemitsu S, Polakis P: The APC protein and E-cadherin form similar but independent complexes with alpha-catenin, beta-catenin, and plakoglobin. J Biol Chem 1995, 270:5549-5555. 
32. Maeda O, Usami N, Kondo M, Takahashi M, Goto H, Shimokata K, Kusugami K, Sekido Y: Plakoglobin (gamma-catenin) has TCF/LEF family-dependent transcriptional activity in beta-catenin-deficient cell line. Oncogene 2004, 23:964-972.

33. Zhurinsky J, Shtutman M, Ben-Ze'ev A: Differential mechanisms of LEF/TCF family-dependent transcriptional activation by beta-catenin and plakoglobin. Mol Cell Biol 2000, 20:4238-4252.

34. Ehrhardt C, Ludwig S: A new player in a deadly game: influenza viruses and the PI3K/Akt signalling pathway. Cell Microbiol 2009, 11:863-871.

35. Martin B, Schneider R, Janetzky S, Waibler Z, Pandur P, Kuhl M, Behrens J, von der Mark K, Starzinski-Powitz A, Wixler V: The LIM-only protein FHL2 interacts with beta-catenin and promotes differentiation of mouse myoblasts. J Cell Biol 2002, 159:113-122.

36. Hedgepeth CM, Conrad LJ, Zhang J, Huang HC, Lee VM, Klein PS: Activation of the Wnt signaling pathway: a molecular mechanism for lithium action. Dev Biol 1997, 185:82-91.

37. Leibovitz A, Stinson JC, McCombs WB III, McCoy CE, Mazur KC, Mabry ND: Classification of human colorectal adenocarcinoma cell lines. Cancer Res 1976, 36:4562-4569.

38. Miyoshi $Y$, Ando $H$, Nagase $H$, Nishisho I, Horii A, Miki $Y$, Mori T, Utsunomiya J, Baba S, Petersen G: Germ-line mutations of the APC gene in 53 familial adenomatous polyposis patients. Proc Natl Acad Sci U S A 1992, 89:4452-4456.

39. Nishisho I, Nakamura Y, Miyoshi Y, Miki Y, Ando H, Horii A, Koyama K, Utsunomiya J, Baba S, Hedge P: Mutations of chromosome 5 q21 genes in FAP and colorectal cancer patients. Science 1991, 253:665-669.

40. Wickline ED, Du Y, Stolz DB, Kahn M, Monga SP: Gamma-catenin at adherens junctions: mechanism and biologic implications in hepatocellular cancer after beta-catenin knockdown. Neoplasia 2013, 15:421-434.

41. Harwood AJ: Regulation of GSK-3: a cellular multiprocessor. Cell 2001, 105:821-824.

42. Desmyter J, Melnick JL, Rawls WE: Defectiveness of interferon production and of rubella virus interference in a line of African green monkey kidney cells (Vero). J Virol 1968, 2:955-961.

43. Yoneyama M, Suhara W, Fujita T: Control of IRF-3 activation by phosphorylation. J Interferon Cytokine Res 2002, 22:73-76.

44. Yang $P, A n$, Liu X, Wen M, Zheng Y, Rui Y, Cao X: The cytosolic nucleic acid sensor LRRFIP1 mediates the production of type I interferon via a beta-catenin-dependent pathway. Nat Immunol 2010, 11:487-494.

45. Takemaru Kl, Moon RT: The transcriptional coactivator CBP interacts with beta-catenin to activate gene expression. J Cell Biol 2000, 149:249-254.

46. Belkowski LS, Sen GC: Inhibition of vesicular stomatitis viral mRNA synthesis by interferons. J Virol 1987, 61:653-660.

47. Staeheli P, Pavlovic J: Inhibition of vesicular stomatitis virus mRNA synthesis by human MxA protein. J Virol 1991, 65:4498-4501.

48. Ank N, West H, Bartholdy C, Eriksson K, Thomsen AR, Paludan SR: Lambda interferon (IFN-lambda), a type III IFN, is induced by viruses and IFNs and displays potent antiviral activity against select virus infections in vivo. J Virol 2006, 80:4501-4509.

49. Stoltz M, Klingstrom J: Alpha/beta interferon (IFN-alpha/beta)independent induction of IFN-lambda1 (interleukin-29) in response to hantaan virus infection. J Virol 2010, 84:9140-9148.

50. Jewell NA, Cline T, Mertz SE, Smirnov SV, Flano E, Schindler C, Grieves JL, Durbin RK, Kotenko SV, Durbin JE: Lambda interferon is the predominant interferon induced by influenza A virus infection in vivo. J Virol 2010, 84:11515-11522

51. Zhang Y, Takami K, Lo MS, Huang G, Yu Q, Roswit WT, Holtzman MJ: Modification of the Stat1 SH2 domain broadly improves interferon efficacy in proportion to $\mathrm{p} 300 / \mathrm{CREB}$-binding protein coactivator recruitment. J Biol Chem 2005, 280:34306-34315.

52. Au WC, Moore PA, Lowther W, Juang YT, Pitha PM: Identification of a member of the interferon regulatory factor family that binds to the interferon-stimulated response element and activates expression of interferon-induced genes. Proc Natl Acad Sci U S A 1995, 92:11657-11661.

53. Holzinger D, Jorns C, Stertz S, Boisson-Dupuis S, Thimme R, Weidmann M, Casanova JL, Haller O, Kochs G: Induction of MxA gene expression by influenza A virus requires type I or type III interferon signaling. J Virol 2007, 81:7776-7785.

54. Kato H, Takeuchi O, Sato S, Yoneyama M, Yamamoto M, Matsui K, Uematsu S, Jung A, Kawai T, Ishii K, Yamaguchi O, Otsu K, Tsujimura T, Koh CS, Reis e
Sousa C, Matsuura Y, Fujita T, Akira S: Differential roles of MDA5 and RIG-I helicases in the recognition of RNA viruses. Nature 2006, 441:101-105.

55. Nakhaei P, Genin P, Civas A, Hiscott J: RIG-I-like receptors: sensing and responding to RNA virus infection. Semin Immunol 2009, 21:215-222.

56. Yoneyama M, Fujita T: Recognition of viral nucleic acids in innate immunity. Rev Med Virol 2010, 20:4-22.

57. Pierce JW, Schoenleber R, Jesmok G, Best J, Moore SA, Collins T, Gerritsen ME: Novel inhibitors of cytokine-induced IkappaBalpha phosphorylation and endothelial cell adhesion molecule expression show antiinflammatory effects in vivo. J Biol Chem 1997, 272:21096-21103.

58. Seth RB, Sun L, Chen ZJ: Antiviral innate immunity pathways. Cell Res 2006, 16:141-147.

59. Engelhardt OG, Fodor E: Functional association between viral and cellular transcription during influenza virus infection. Rev Med Virol 2006, 16:329-345.

60. Pauli EK, Schmolke M, Wolff T, Viemann D, Roth J, Bode JG, Ludwig S: Influenza A virus inhibits type I IFN signaling via NF-kappaB-dependent induction of SOCS-3 expression. PLOS Pathog 2008, 4:e1000196.

61. Wurzer WJ, Planz O, Ehrhardt C, Giner M, Silberzahn T, Pleschka S, Ludwig S: Caspase 3 activation is essential for efficient influenza virus propagation. EMBO J 2003, 22:2717-2728.

62. Shapira SD, Gat-Viks I, Shum BO, Dricot A, de Grace MM, Wu L, Gupta PB, Hao T, Silver SJ, Root DE, Hill DE, Regev A, Hacohen N: A physical and regulatory map of host-influenza interactions reveals pathways in $\mathrm{H} 1 \mathrm{~N} 1$ infection. Cell 2009, 139:1255-1267.

63. Konig R, Stertz S, Zhou Y, Inoue A, Hoffmann HH, Bhattacharyya S, Alamares JG, Tscherne DM, Ortigoza MB, Liang Y, Gao Q, Andrews SE, Bandyopadhyay S, De Jesus P, Tu BP, Pache L, Shih C, Orth A, Bonamy G, Miraglia L, Ideker T, Garcia-Sastre A, Young JA, Palese P, Shaw ML, Chanda SK: Human host factors required for influenza virus replication. Nature 2010, 463:813-817.

64. Kumar A, Zloza A, Moon RT, Watts J, Tenorio AR, Al-Harthi L: Active beta-catenin signaling is an inhibitory pathway for human immunodeficiency virus replication in peripheral blood mononuclear cells. J Virol 2008, 82:2813-2820.

65. Bose S, Banerjee AK: Beta-catenin associates with human parainfluenza virus type 3 ribonucleoprotein complex and activates transcription of viral genome RNA in vitro. Gene Expr 2004, 11:241-249.

66. Labalette C, Renard CA, Neuveut C, Buendia MA, Wei Y: Interaction and functional cooperation between the LIM protein $\mathrm{FHL} 2, \mathrm{CBP} / \mathrm{p} 300$, and beta-catenin. Mol Cell Biol 2004, 24:10689-10702.

67. Levy L, Wei Y, Labalette C, Wu Y, Renard CA, Buendia MA, Neuveut C: Acetylation of beta-catenin by $\mathrm{p} 300$ regulates beta-catenin-Tcf4 interaction. Mol Cell Biol 2004, 24:3404-3414.

68. Merika M, Williams AJ, Chen G, Collins T, Thanos D: Recruitment of CBP/ p300 by the IFN beta enhanceosome is required for synergistic activation of transcription. Mol Cell 1998, 1:277-287.

69. Wetering VDM, Oosterwegel M, Dooijes D, Clevers H: Identification and cloning of TCF-1, a T lymphocyte-specific transcription factor containing a sequence-specific HMG box. EMBO J 1991, 10:123-132.

70. Zhu J, Coyne CB, Sarkar SN: PKC alpha regulates sendai virus-mediated interferon induction through HDAC6 and beta-catenin. EMBO J 2011, 30:4838-4849.

71. Baril M, Es-Saad S, Chatel-Chaix L, Fink K, Pham T, Raymond VA, Audette K, Guenier AS, Duchaine J, Servant M, Bilodeau M, Cohen E, Grandvaux N Lamarre D: Genome-wide RNAi screen reveals a new role of a WNT/ CTNNB1 signaling pathway as negative regulator of virus-induced innate immune responses. PLoS Pathog 2013, 9:e1003416.

72. Angelova M, Zwezdaryk K, Ferris M, Shan B, Morris CA, Sullivan DE: Human cytomegalovirus infection dysregulates the canonical Wnt/beta-catenin signaling pathway. PLOS Pathog 2012, 8:e1002959.

73. Deng J, Miller SA, Wang HY, Xia W, Wen Y, Zhou BP, Li Y, Lin SY, Hung MC: Beta-catenin interacts with and inhibits NF-kappa B in human colon and breast cancer. Cancer Cell 2002, 2:323-334.

74. Hwang I, Choi YS, Jeon MY, Jeong S: NF-kappaB p65 represses betacatenin-activated transcription of cyclin D1. Biochem Biophys Res Commun 2010, 403:79-84.

75. Saegusa M, Hashimura M, Kuwata T, Hamano M, Okayasu I: Crosstalk between NF-kappaB/p65 and beta-catenin/TCF4/p300 signalling pathways through alterations in GSK-3beta expression during transdifferentiation of endometrial carcinoma cells. J Pathol 2007, 213:35-45.

76. Masui O, Ueda Y, Tsumura A, Koyanagi M, Hijikata M, Shimotohno K: RelA suppresses the Wnt/beta-catenin pathway without exerting trans-acting transcriptional ability. Int J Mol Med 2002, 9:489-493. 
77. Seyer R, Hrincius ER, Ritzel D, Abt M, Mellmann A, Marjuki H, Kuhn J, Wolff T, Ludwig S, Ehrhardt C: Synergistic adaptive mutations in the hemagglutinin and polymerase acidic protein lead to increased virulence of pandemic $2009 \mathrm{H} 1 \mathrm{~N} 1$ influenza A virus in mice. J Infect Dis 2012, 205:262-271.

78. Nordhoff C, Hillesheim A, Walter BM, Haasbach E, Planz O, Ehrhardt C, Ludwig S, Wixler V: The adaptor protein FHL2 enhances the cellular innate immune response to influenza A virus infection. Cell Microbiol 2012, 14:1135-1147.

79. Livak KJ, Schmittgen TD: Analysis of relative gene expression data using real-time quantitative PCR and the 2(-delta delta $C(T)$ ) method. Methods 2001, 25:402-408.

80. Tang ED, Wang CY: MAVS self-association mediates antiviral innate immune signaling. J Virol 2009, 83:3420-3428.

81. Martin BT, Kleiber K, Wixler V, Raab M, Zimmer B, Kaufmann M, Strebhardt K: FHL2 regulates cell cycle-dependent and doxorubicin-induced p21Cip1/ Waf1 expression in breast cancer cells. Cell Cycle 2007, 6:1779-1788.

82. Vermeulen L, De WG, Van DP, Vanden BW, Haegeman G: Transcriptional activation of the NF-kappaB p65 subunit by mitogen- and stressactivated protein kinase-1 (MSK1). EMBO J 2003, 22:1313-1324.

83. Ludwig S, Ehrhardt C, Neumeier ER, Kracht M, Rapp UR, Pleschka S: Influenza virus-induced AP-1-dependent gene expression requires activation of the JNK signaling pathway. J Biol Chem 2001, 276:10990-10998.

84. Bradford MM: A rapid and sensitive method for the quantitation of microgram quantities of protein utilizing the principle of protein-dye binding. Anal Biochem 1976, 72:248-254.

85. Iwamura T, Yoneyama M, Yamaguchi K, Suhara W, Mori W, Shiota K, Okabe Y, Namiki H, Fujita T: Induction of IRF-3/-7 kinase and NF-kappaB in response to double-stranded RNA and virus infection: common and unique pathways. Genes Cells 2001, 6:375-388.

86. Carr SM, Carnero E, Garcia-Sastre A, Brownlee GG, Fodor E: Characterization of a mitochondrial-targeting signal in the PB2 protein of influenza viruses. Virology 2006, 344:492-508.

87. Dierkes R, Warnking K, Liedmann S, Ludwig S, Ehrhardt C: The Rac1 Inhibitor NSC23766 exerts anti-influenza virus properties by affecting the viral polymerase complex activity. PLoS One 2014, 9:e88520.

doi:10.1186/1478-811X-12-29

Cite this article as: Hillesheim et al: $\beta$-catenin promotes the type I IFN synthesis and the IFN-dependent signaling response but is suppressed by influenza A virus-induced RIG-I/NF-KB signaling. Cell Communication and Signaling 2014 12:29.

\section{Submit your next manuscript to BioMed Central and take full advantage of:}

- Convenient online submission

- Thorough peer review

- No space constraints or color figure charges

- Immediate publication on acceptance

- Inclusion in PubMed, CAS, Scopus and Google Scholar

- Research which is freely available for redistribution 